\title{
Slag Properties in the Primary Production Process of Mn-Ferroalloys
}

\author{
MERETE TANGSTAD, SERGEY BUBLIK, SHOKOUH HAGHDANI, \\ KRISTIAN ETIENNE EINARSRUD, and KAI TANG
}

The thermodynamic and kinetic properties of the carbothermic reduction of $\mathrm{MnO}$ in the five-component slag, $\mathrm{MnO}-\mathrm{SiO}_{2}-\mathrm{CaO}-\mathrm{MgO}-\mathrm{Al}_{2} \mathrm{O}_{3}$, is critical in the production process of $\mathrm{Mn}$-ferroalloys. While the reduction rate is mainly dependent on the presence of a solid $\mathrm{MnO}$ phase in the slag for $\mathrm{Mn}-\mathrm{Fe}$-alloys, the rate for the $\mathrm{Mn}-\mathrm{Si}-\mathrm{Fe}$ alloys has two distinct steps, a slow step followed by a fast step. The extent of the slow step has been shown to be dependent on the $\mathrm{S}$ content in the slag. The thermo-physical properties of viscosity, density, interfacial tension and electrical resistivity is reviewed, and these properties are mainly determined by the total basicity.

https://doi.org/10.1007/s11663-021-02347-8

(C) The Author(s) 2021

\section{OVERVIEW OF THE MN-ALLOY PRODUCTION PROCESS}

MN-FERROALLOYS are alloys containing mostly $\mathrm{Mn}, \mathrm{Fe}, \mathrm{Si}$ and $\mathrm{C}$. Manganese is the main element and typically accounts for between 60 and $80 \mathrm{wt}$ pct of the alloy. Iron will always follow the raw materials and practically all iron in the raw materials will end up in the alloy. Silicon may be less than 1 pct or up to 30 pct. Less than 1 pct $\mathrm{Si}$ is usually called FeMn (ferromanganese) and alloys with 16 to 30 pct is called SiMn (silicomanganese). The metal will be saturated with carbon from the furnace and will be 7 pct $\mathrm{C}$ for FeMn and for SiMn the carbon content is dependent on the amount of silicon. Typically, for $18 \mathrm{pct} \mathrm{Si}$ the carbon content is less than 2 pct C. As for most reduction processes, the metal composition is determined by the slag properties, and the slag in the $\mathrm{Mn}$-ferroalloy will mainly be $\mathrm{MnO}, \mathrm{SiO}_{2}$, $\mathrm{MgO}, \mathrm{CaO}$ and $\mathrm{Al}_{2} \mathrm{O}_{3}$ as all the iron ends up in the metal. There are a number of definitions of slag basicity that can be used to describe the composition of the slag. In this paper, the basicity will be given as $B=\frac{\mathrm{CaO}+\mathrm{MgO}}{\mathrm{SiO}_{2}+\mathrm{Al}_{2} \mathrm{O}_{3}}$. Trace elements are counted as basic or acid oxides, depending on their nature.

MERETE TANGSTAD, SERGEY BUBLIK, SHOKOUH HAGHDANI, KRISTIAN ETIENNE EINARSRUD are with the Department of Material Science and Engineering, Norwegian University of Science and Technology, 7491 Trondheim, Norway. Contact e-mail: Merete.Tangstad@ntnu.no KAI TANG is with the SINTEF Industry, SINTEF, 7465 Trondheim, Norway.

Manuscript submitted March 21, 2021; accepted October 2, 2021.

Article published online November 1, 2021.
The temperatures in the closed Mn-ferroalloy furnaces can be from $200{ }^{\circ} \mathrm{C}$ to $600{ }^{\circ} \mathrm{C}$ on the top of the charge to $1500{ }^{\circ} \mathrm{C}$ to $1600{ }^{\circ} \mathrm{C}$ in the tapped slag. This means that in upper part of the furnace, the low temperature zone, the raw materials will be solid, and when it enters the area on top of the coke-bed, around $1200{ }^{\circ} \mathrm{C}$ to $1400{ }^{\circ} \mathrm{C}$, the raw materials will melt into a primary slag. This slag will coexist with the solid carbon materials added to the furnace (Figure 1). This paper will discuss the knowledge we have on MnO-slags related to the primary production of FeMn or SiMn inside the Submerged Arc Furnace. First we will discuss the mechanism of slag formation, the thermodynamics, and the kinetics. Next, a summary of key slag properties is presented. These key properties include the $\mathrm{MnO}$ slag structure, viscosity, density, interfacial tension and wetting properties, and electrical conductivity. The pathway of the slag considered in this work will start with the production of a primary slag from the raw materials, followed by the reduction of valuable elements into a Mn-alloy and finally the drainage, or tapping, from the furnace.

Most of the slag will as discussed later, follow the increasing temperature. Some slag may however be circulated into the low temperature area. In Mn-alloy production, slags have been known to be sputtered up to the cold furnace top from the high temperature area as seen in Figure 2. ${ }^{[2,3]}$ This is believed to happen if the permeability of the charge is poor, and the raw materials are not heated gradually, or if too violent foaming of the slag occurs. 

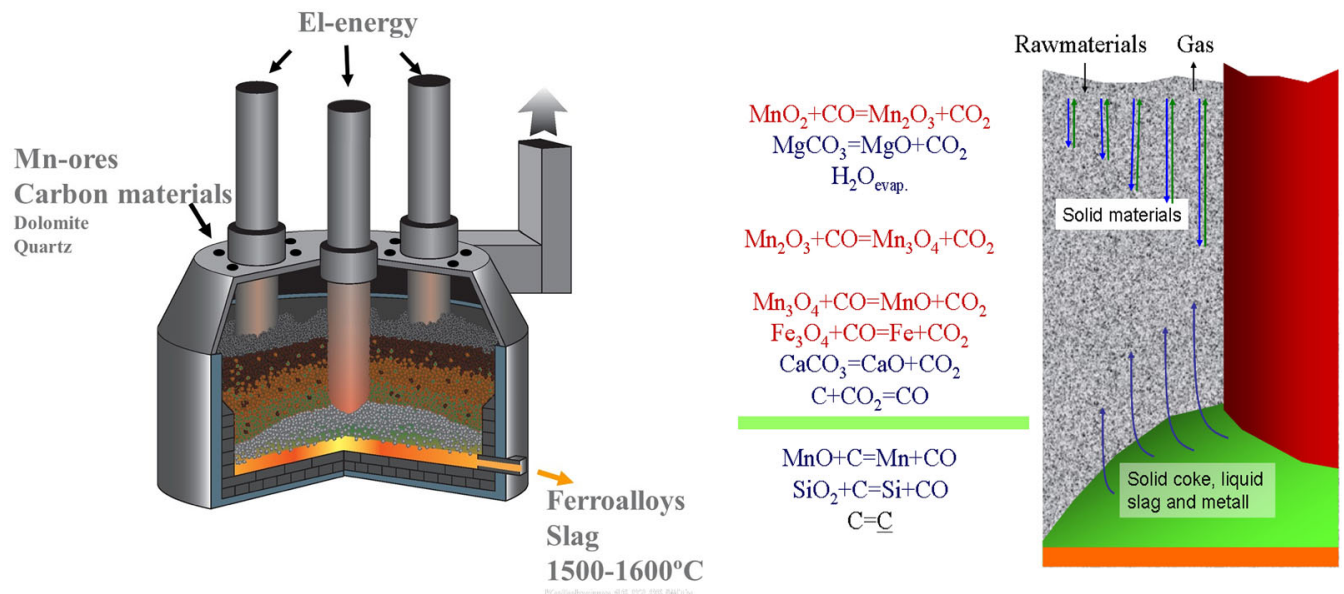

Fig. 1-Overview of a typical closed furnace producing Mn-alloys (left) and an illustration of zones and reactions around one of the electrodes (right). ${ }^{[1]}$ (Figure is reprinted with permission from Ref. 1).
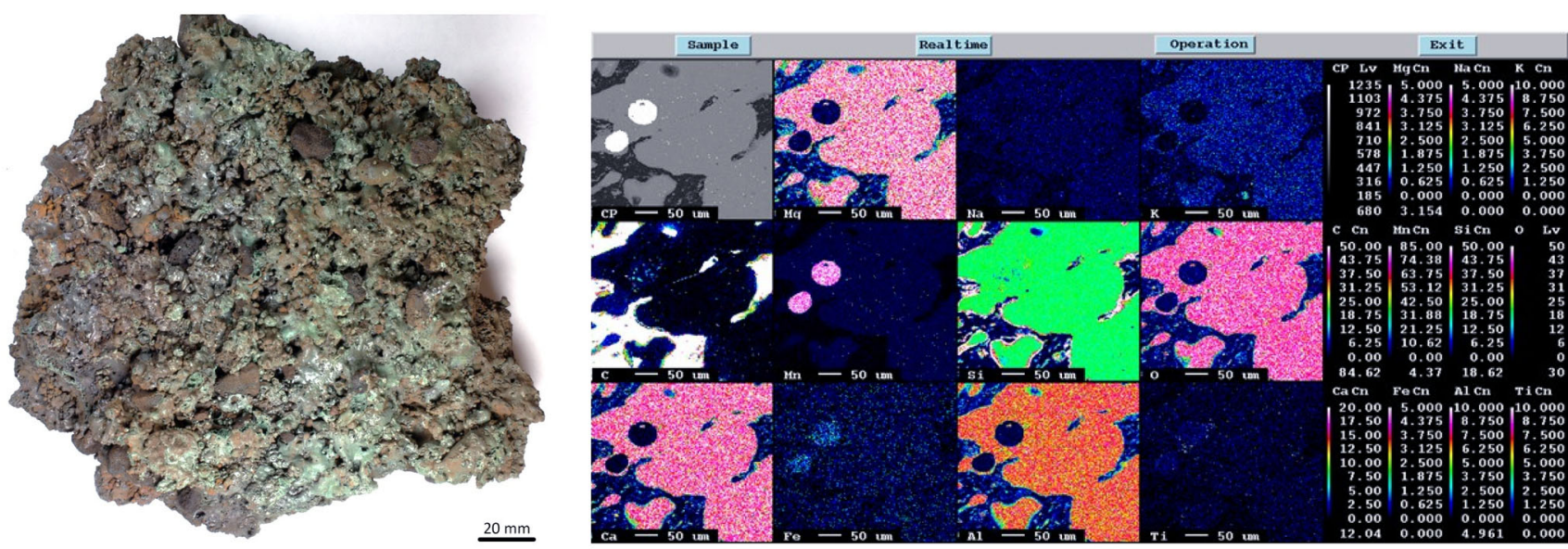

Fig. 2-Slag infiltrated charge sample at top of the furnace charge taken from a FeMn furnace (left picture) showing low alkali binder phase $(\text { right })^{[4]}$.

\section{MELTING OF ORES AND REDUCTION OF PRIMARY SLAGS}

The melting of the raw materials to a primary slag and the following reduction to Mn-ferroalloys are closely related. It is hence appropriate to start with the Mn-bearing raw materials and the primary slag it produces at around $1200{ }^{\circ} \mathrm{C}$ and up. Table I show some typical ores, where the metallurgical grade ore typically have more than 35 pct $\mathrm{Mn}$. After being heated in solid state in the prereduction zone, all higher manganese $\left(\mathrm{MnO}_{2}, \mathrm{Mn}_{2} \mathrm{O}_{3}\right.$ and $\left.\mathrm{Mn}_{3} \mathrm{O}_{4}\right)$ has been reduced to $\mathrm{MnO}$, the iron oxides are reduced to metallic phase, and all the carbonates $\left(\mathrm{CaCO}_{3}, \mathrm{MgCO}_{3}, \mathrm{MnCO}_{3}\right)$ are decomposed to basic oxides $(\mathrm{CaO}, \mathrm{MgO}$ and $\mathrm{MnO})$. The main elements in the oxide phase will now be the 5 components $\mathrm{MnO}-\mathrm{SiO}_{2}-\mathrm{Al}_{2} \mathrm{O}_{3}-\mathrm{CaO}-\mathrm{MgO}$. Table II shows the chemical composition calculated from the chemical analyses of the ore of the primary slag. It can be noted that there will also be a number of trace elements like $\mathrm{TiO}_{2}, \mathrm{~K}_{2} \mathrm{O}, \mathrm{BaO}$, however these will not be discussed further here.
The five-component pre-reduced Mn-ores, typically containing around 70 pet $\mathrm{MnO}$, will as it melts down dissolve fluxes. The fluxes can typically be "pre-reduced" limestone or dolomite or quartz and reduced $\mathrm{MnO}$-slags if $\mathrm{SiMn}$ is produced. In the liquid (or partly liquid) state, the $\mathrm{MnO}$ and $\mathrm{SiO}_{2}$ may be reduced to metallic $\mathrm{Mn}-\mathrm{Fe}-\mathrm{Si}-\mathrm{C}_{\text {saturated }}$ alloy according to reactions [1] and [2], where the parentheses denote a slag phase and underscored denotes metallic phases. The carbon can be solid carbon, i.e., coke particles, or carbon dissolved in the metal. Some of the $\mathrm{MnO}$ and $\mathrm{SiO}_{2}$ still will remain in the slag, and the tapped slag will thus be the same 5-component slag containing $\mathrm{MnO}, \mathrm{SiO}_{2}$, $\mathrm{Al}_{2} \mathrm{O}_{3}, \mathrm{CaO}$ and $\mathrm{MgO}$.

$$
\begin{aligned}
& (\mathrm{MnO})+\mathrm{C}=\underline{\mathrm{Mn}}+\mathrm{CO}_{\mathrm{g}} \\
& \left(\mathrm{SiO}_{2}\right)+2 \mathrm{C}=\underline{\mathrm{Si}}+2 \mathrm{CO}_{\mathrm{g}}
\end{aligned}
$$


Table I. Typical Analyses of Mn-Ores ${ }^{[1,5,6]}$

\begin{tabular}{|c|c|c|c|c|c|c|c|c|c|}
\hline Manganese Ore & & $\mathrm{Mn}$ & $\mathrm{Fe}$ & $\mathrm{SiO} 2$ & $\mathrm{~A} 12 \mathrm{O} 3$ & $\mathrm{MgO}$ & $\mathrm{CaO}$ & $\mathrm{P}$ & $\mathrm{CO} 2$ \\
\hline Comilog MMA & Gabon & 50.5 & 2.7 & 4.0 & 5.5 & 0.3 & 0.2 & 0.11 & 0.1 \\
\hline Comilog Sinter & & 58.5 & 3.5 & 7.0 & 6.5 & 0.0 & 0.1 & 0.12 & 0.0 \\
\hline Mn-Nodules & Mexico & 37.7 & 7.9 & 14.9 & 3.9 & 8.1 & & 0.085 & \\
\hline Asman 48 & South Africa & 51.3 & 10.1 & 5.5 & 0.4 & 0.7 & 4.3 & 0.04 & 0.8 \\
\hline Mamatwan & & 37.8 & 4.6 & 4.0 & 0.5 & 3.5 & 14.7 & 0.02 & 17.0 \\
\hline Gloria & & 39.1 & 5.0 & 5.7 & 0.3 & 3.8 & 12.7 & 0.02 & 15.4 \\
\hline Wessel 38 pct & & 42.3 & 13.2 & 4.9 & 2.5 & 1.0 & 6.0 & 0.04 & 3.6 \\
\hline Wessel 50 pct & & 50.2 & 10.0 & 3.6 & 0.4 & 1.0 & 5.6 & 0.04 & 2.6 \\
\hline Groote Eylandt & Australia & 48.8 & 4.2 & 6.9 & 4.2 & 0.1 & 0.1 & 0.09 & 0.5 \\
\hline Amapa Sinter & Brazil & 49.1 & 9.6 & 7.6 & 7.6 & 0.5 & 0.8 & 0.10 & 0.0 \\
\hline Amapa Miudo 40 & & 41.3 & 12.5 & 5.9 & 8.1 & 0.1 & 0.3 & 0.11 & 3.5 \\
\hline CVRD Sinter & & 54.5 & 4.7 & 5.4 & 8.7 & 0.5 & 1.9 & 0.11 & 0.2 \\
\hline CVRD Lump & & 45.0 & 4.7 & 2.6 & 8.6 & 0.2 & 0.2 & 0.09 & 14.4 \\
\hline Nikopol-Oxide & Ukraine & $29-43$ & $1-3$ & $11-24$ & $1.4-3.3$ & $0.8-2$ & $4-10$ & $0.15-0.3$ & \\
\hline Nikopol-Pyrolusite & & 47.5 & 0.65 & 8.6 & 1.6 & 0.6 & 2 & 0.2 & \\
\hline Nikopol-Carbonate & & $22-28$ & $1.5-3$ & $13-16$ & $1.7-2.3$ & $1.5-2.2$ & $7-13$ & $0.3-0.6$ & \\
\hline Tchiatura-Oxide & Georgia & $30-44$ & $0.7-4$ & $6-17$ & $1.3-2.6$ & $1-2.5$ & $3.8-5.5$ & $0.1-0.4$ & \\
\hline Tchiatura-Pyrolusite & & 28 & 1.3 & 17.6 & 2.9 & 1.5 & 8.2 & 0.2 & \\
\hline Tchiatura-carbonate & & $23-25$ & 1.3 & $16-17$ & 2 & 2.5 & 10 & 0.15 & \\
\hline Zapadny Kamys & Kazakhstan & $17-19$ & $5-6$ & $40-42$ & $5-6.5$ & $1-1.5$ & $1.2-1.7$ & 0.035 & \\
\hline
\end{tabular}

A number of industrial-, and pilot scale- tap-slag composition have been reported. For FeMn slags the $\mathrm{MnO}$ content varies from 15 to $40 \mathrm{wt}$ pct depending on the basicity. ${ }^{[1,5,7-12]}$ High basicity charges, that is basicities above 1.1 , typically have less than 25 pct $\mathrm{MnO}$. Basicities around 0.7 typically has $35-40$ pet $\mathrm{MnO}$, and this is close to the liquidus line at $1500{ }^{\circ} \mathrm{C}$, which is reported to be close to the tapping temperature. ${ }^{[13]}$ Some smaller furnaces, e.g., a 21 MVA furnace, ${ }^{[9]}$ show an $\mathrm{MnO}$ content as low as 19 pet $\mathrm{MnO}$ with a basicity of 0.9 , and it is speculated if smaller furnaces may produce lower $\mathrm{MnO}$ contents. Acid slags with a basicity 0.2-0.3 will also tap at about 40 pet $\mathrm{MnO}$.

For SiMn slags a typical $\mathrm{Si}$ content is $15-18$ pct Si, and to obtain this around 40 pct $\mathrm{SiO}_{2}$ is needed in the slag. Industrially, less than $20 \mathrm{pct} \mathrm{MnO}$ is remaining in the slag, and it can be down to 5-10 pct. In pilot scale operation the $\mathrm{MnO}$ content in SiMn slags are typically seen to be a bit higher than the industrial slags, that is up to 25 pet $\mathrm{MnO} .^{[1,5,14-19]}$

To sum this up, FeMn charges will be reduced from a primary slag with more than $60 \mathrm{pct} \mathrm{MnO}$ to 15 to $40 \mathrm{pct}$ $\mathrm{MnO}$ in the tapped slag, while SiMn charge mixes is reduced from a primary slag with more than $35 \mathrm{pct}$ $\mathrm{MnO}$ (as the Mn-sources are mixed with both fluxes and quartz) to around 10 pet $\mathrm{MnO}$ tapped at $1600{ }^{\circ} \mathrm{C}^{[16]}$

The slag composition will of course be affected by the temperature. Due to reported tapping temperatures of around $1500{ }^{\circ} \mathrm{C}$ for $\mathrm{FeMn}^{[13]}$ and $1600{ }^{\circ} \mathrm{C}$ for SiMn tappings, ${ }^{[16]}$ one assumes that this can also be the temperatures inside the high temperature zones in the furnaces. As the temperatures are varying both due to the electrode paths in the furnace, given by the coke-bed size and shape, and raw material properties, the temperature in the high temperature zone will vary both in space and in time.

\section{A. Phase Composition in Mn-Slags and Melting Behaviour Of Ores.}

The melting behaviour of the above described 5 component system can be simplified to the $\mathrm{MnO}-\mathrm{SiO}_{2}$ system where "MnO" in reality represents the basic oxides $\mathrm{MnO}, \mathrm{CaO}$, and $\mathrm{MgO}$ and " $\mathrm{SiO}_{2}$ " represent the acid oxides $\mathrm{SiO}_{2}$ and $\mathrm{Al}_{2} \mathrm{O}_{3}$ as illustrated in Figure 3. Although $\mathrm{Al}_{2} \mathrm{O}_{3}$ is an amphoteric oxide, it will for manganese slags behave as an acidic oxide, though less acid in more acid SiMn slags vs. more basic FeMn slags. ${ }^{[16,20]}$

For FeMn slags, containing a high amount of $\mathrm{MnO}$, the reduction will start when a liquid phase is present in the material that is above the solidus, represented by the $1306{ }^{\circ} \mathrm{C}$ horizontal line in Figure 3. The reduction may hence start in the area of $1300{ }^{\circ} \mathrm{C}$ according to the equilibrium state. At this point, the reduction starts and hence it is believed that the endothermic reaction (reaction [1]) will consume more energy and hence the heating rate will decrease drastically. The reduction will go through a two-phase area, and the primary slag will consist of a liquid with a solid $\mathrm{MnO}$ phase as seen in Figure 4. The presence of a solid $\mathrm{MnO}$ phase has two major consequences; first it will have a high impact on the activity of $\mathrm{MnO}$ and secondly it will have a large effect on the flow properties (i.e., viscosity) of the slag.

Even if the slag is partly molten, it will not be able to flow into a coke-bed as illustrated by an ore particle being heated and reduced in Figure 5. The partly liquid slag will not flow into the coke bed until it is reduced down to the point where no solid $\mathrm{MnO}$ is present, where the slag viscosity will be at its minimum as indicated in Figure 6 (left figure). It must also be mentioned that in addition to slag viscosity being affected by solid $\mathrm{MnO}$ particles, the size of the coke particles will also affect the 


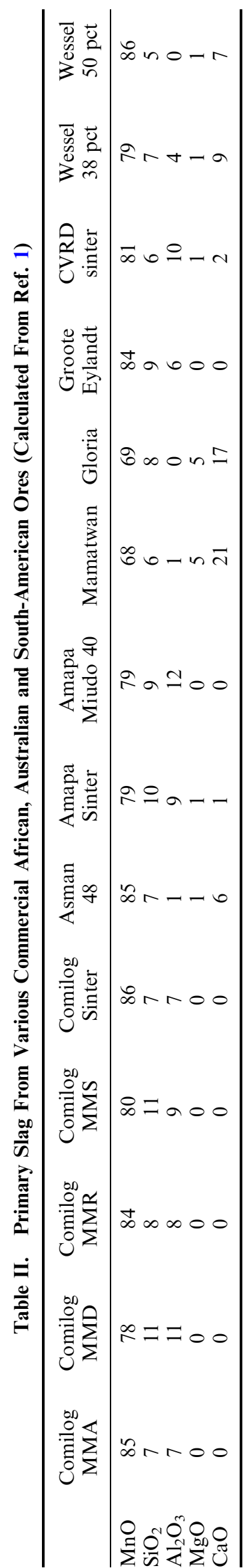

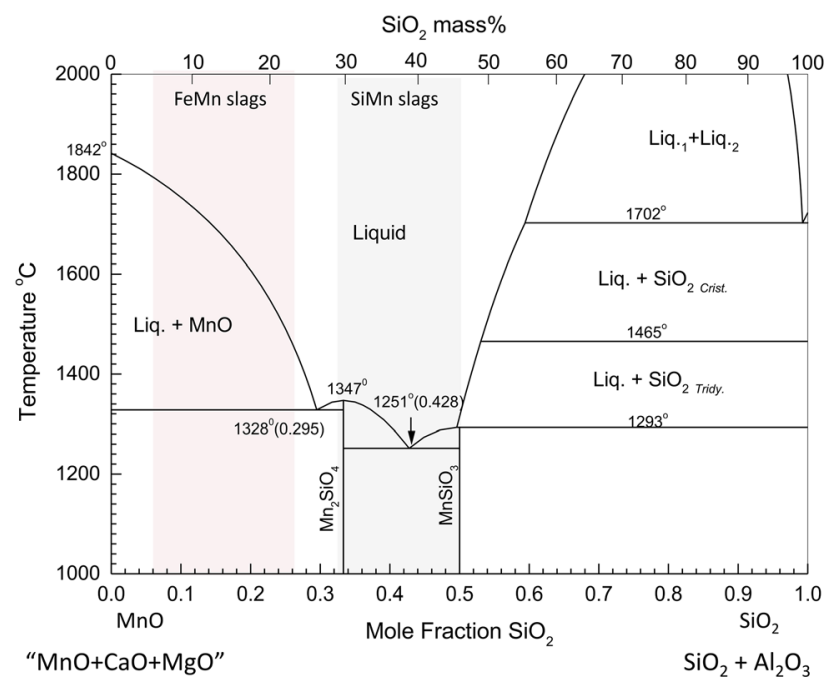

Fig. 3- $-\mathrm{MnO}-\mathrm{SiO}_{2}$ phase diagram indicating the primary slag in FeMn and SiMn production, where $\mathrm{MnO}$ represents the basic oxides of $\mathrm{MnO}+\mathrm{CaO}+\mathrm{MgO}$ and $\mathrm{SiO}_{2}$ represents the acid oxides such as $\mathrm{SiO}_{2}+\mathrm{Al}_{2} \mathrm{O}_{3}$.

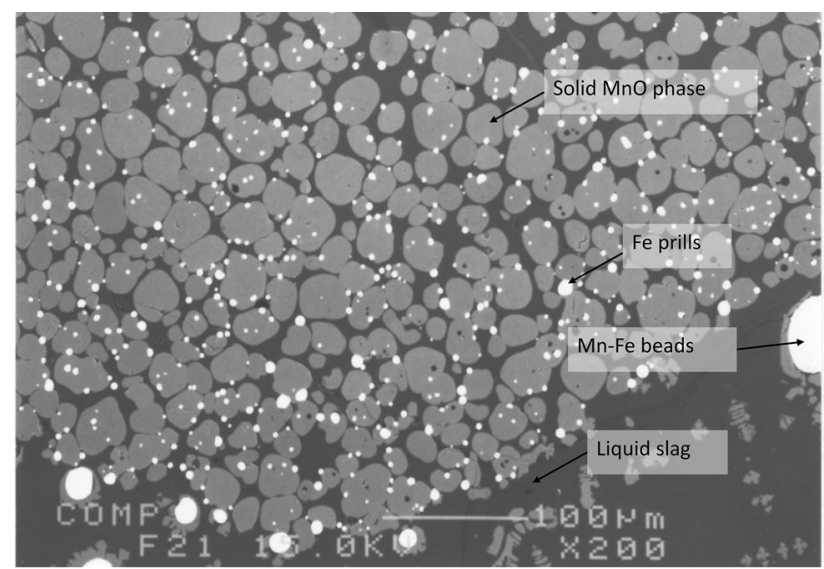

Fig. 4-Partly reduced FeMn slag containing solid $\mathrm{MnO}$ spheres in a liquid phase (adapted from Ref. 13).

flow of the slag into the coke bed as seen in Figure 6 (right picture) where the reduced slag is lingering on top of the coke particles.

The phase composition in slags from primary slag composition to tap-slag compositions may be illustrated with the ternary phase diagrams $\mathrm{MnO}-\mathrm{SiO}_{2}-\mathrm{Al}_{2} \mathrm{O}_{3}$ that represents the Comilog ore, Groote Eyland ore and the South-American ores, and the $\mathrm{MnO}-\mathrm{SiO}_{2}-\mathrm{CaO}$ diagram representing the South-African ores. While experimental work determining the slag phases exists, ${ }^{[22-24]}$ we will in this paper use the FactSage databases to illustrate the reduction path, which equal the basicity line, as shown in Figure 7. There may of course be some deviations between experimental work and FactSage, ${ }^{[23]}$ but the overall correlation is expected to be acceptable. From the Figure 7, the main reduction path seen in the binary $\mathrm{MnO}-\mathrm{SiO}_{2}$ phase diagram can be found. The high $\mathrm{MnO}$ ores will, when enough liquid phase is formed, start to reduce in a liquid + solid $\mathrm{MnO}$ phase area. As the 


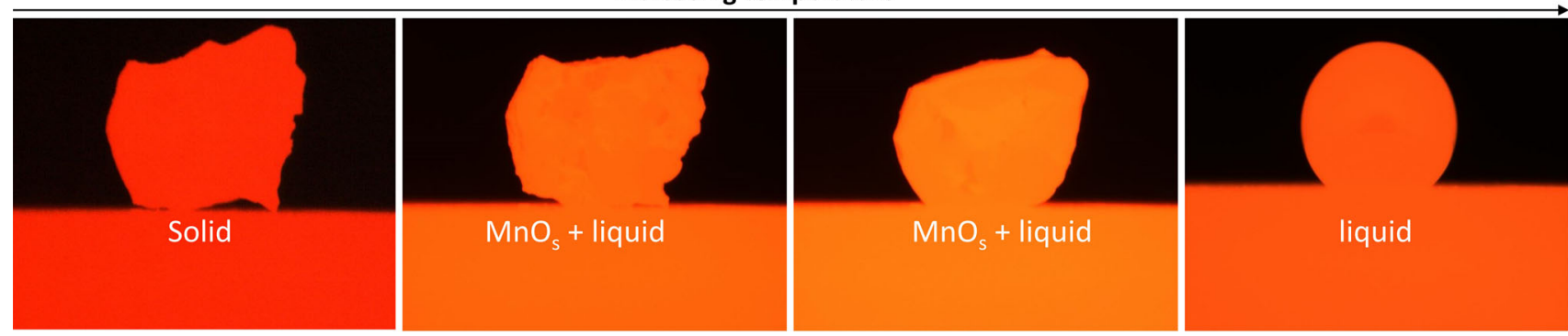

Fig. 5-Mn-ore particle being heated in $\mathrm{CO}$ gas on a carbon substrate.
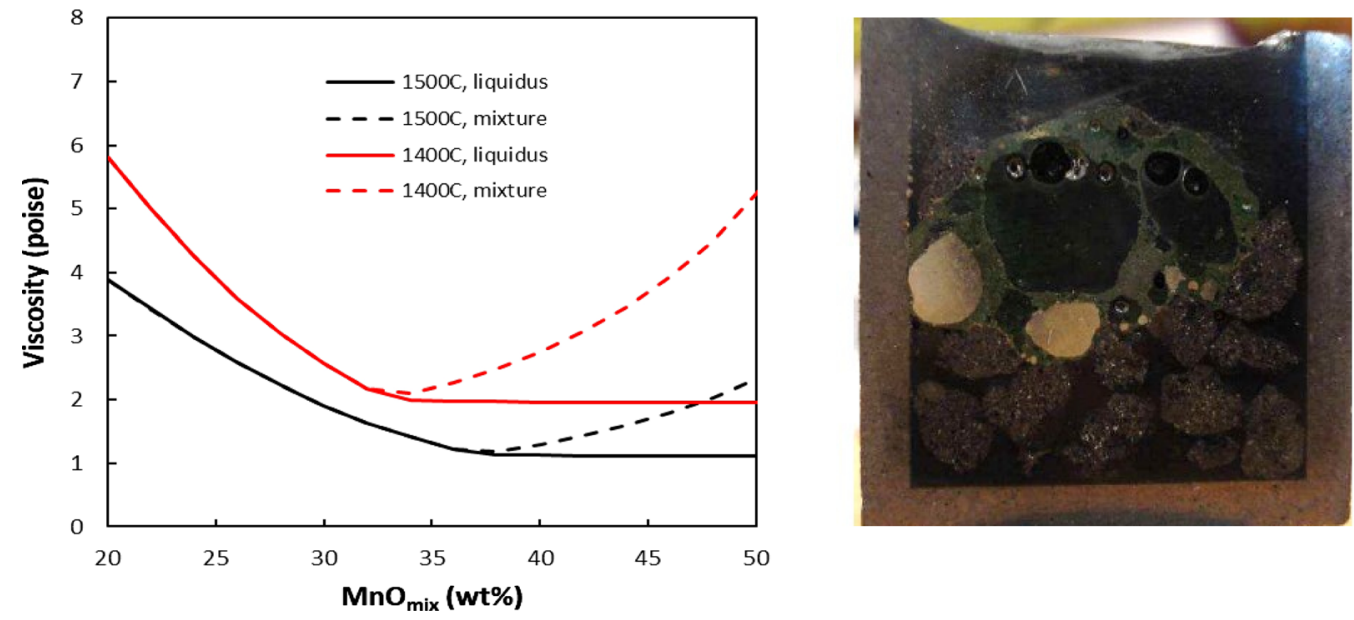

Fig. 6-FeMn-production: Slag viscosity during cooling adapted from Ref. 1 (left) and example of reduced slag from Comilog ore at $1600{ }^{\circ} \mathrm{C}^{[21]}$ (right).

reduction proceeds to a lower $\mathrm{MnO}$ content, the solid $\mathrm{MnO}$ phase will gradually dissolve until the saturation composition is reached. It is also seen that this saturation compostion will be reached at a lower $\mathrm{MnO}$ content with higher basicities, which can also be seen in Figure 8 . As mentioned above, the tap-slag is quite close to the saturation composition of around 30-40 pet $\mathrm{MnO}$ for a basicity of 0.7 and around 20 pet $\mathrm{MnO}$ at basicities of 1.1. This is believed to be due to the activity of $\mathrm{MnO}$, and the effect the activity of $\mathrm{MnO}$ has on the reaction rate, as will be discussed later.

Depending on the mineralogy and distribution of minerals in the original ores, the raw materials will not always behave close to the equilibrium state given by the phase diagrams. A large effort has hence been done to find the melting behaviour of the ores under a certain heating rate with carbon present, that is when it starts to soften, also called initial melting, when it melts, and when it is completely molten (i.e the liquidus is obtained either due to a high temperature and/or to a low $\mathrm{MnO}$ content. $^{[3,6,19,25-31]}$ ) These stages represent the steps an ore particle experiences in the Submerged Arc Furnace and are illustrated in Figure 5. While large variation exists in the results, the main trend is that more acid materials will produce a larger amount of liquid phase at a lower temperatures, in agreement with the phase diagrams already discussed. The materials will also produce a larger amount of liquid phase at low temperatures when it has been heat-treated at high temperatures. This can be explained by the basic and acid minerals mixed in an ore has dissolved into silicate phases when heat-treated and will hence melt at lower temperatures. To exemplify this according to Figure 3 for a constant heating rate: if a pre-reduced ore contains the two individual phases $\mathrm{MnO}$, with a melting point above $1800{ }^{\circ} \mathrm{C}$, and $\mathrm{SiO}_{2}$, with a melting point above $1700{ }^{\circ} \mathrm{C}$, it will start to behave as partly liquid material at higher temperatures, than a $\mathrm{Mn}_{2} \mathrm{SiO}_{4}$ phase that has a melting point of $1363{ }^{\circ} \mathrm{C}$ due to kinetic restraints. It is of course the time to reach equilibrium state that will increase, however in a furnace with a fixed heating rate, this will then happen at a higher temperature (Figure 9).

When it comes to the primary slag formation for $\mathrm{SiMn}$ production, the average composition will be in the green area in Figure 3, as quartz is also added to the charge mix. Many producers are also using tap-slag from the FeMn production as a raw material. Since this slag contains around $30-40$ pet $\mathrm{MnO}$, it will be molten already at around $1250{ }^{\circ} \mathrm{C}$, in the same area as the average primary slag composition. Two hypotheses exist for the reduction step in SiMn furnaces:

1. The Mn-sources will dissolve the quartz first, and the reduction will hence be from the average charge composition, that is the average primary slag com- 


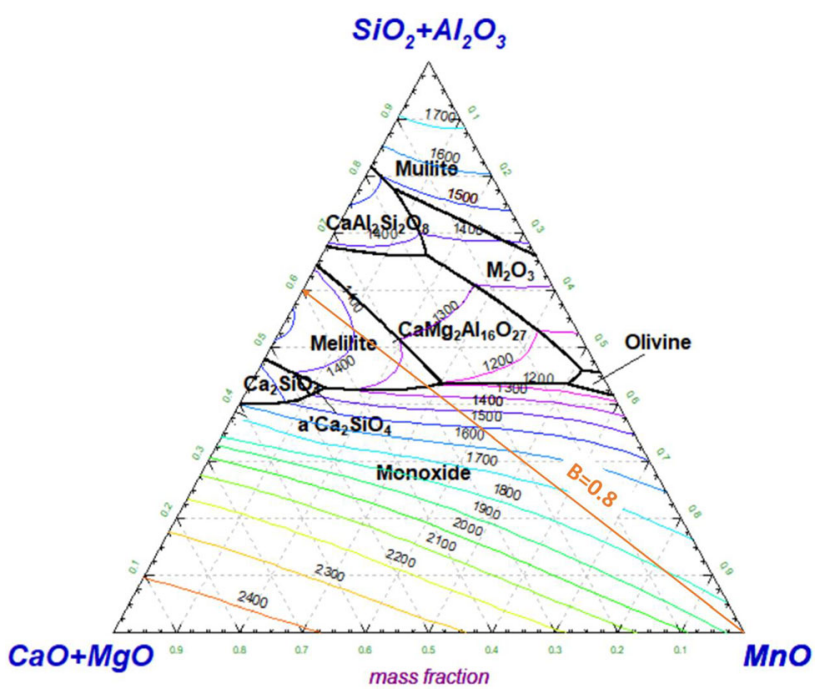

Fig. 7-Liquidus surface of $\mathrm{MnO}-\mathrm{SiO}_{2}-\mathrm{Al}_{2} \mathrm{O}_{3}-\mathrm{CaO}-\mathrm{MgO}(\mathrm{A} / \mathrm{S}=0.8$, $\mathrm{C} / \mathrm{M}=7)$ slags calculated by FactSage software package. The basicity line of 0.8 is indicated.

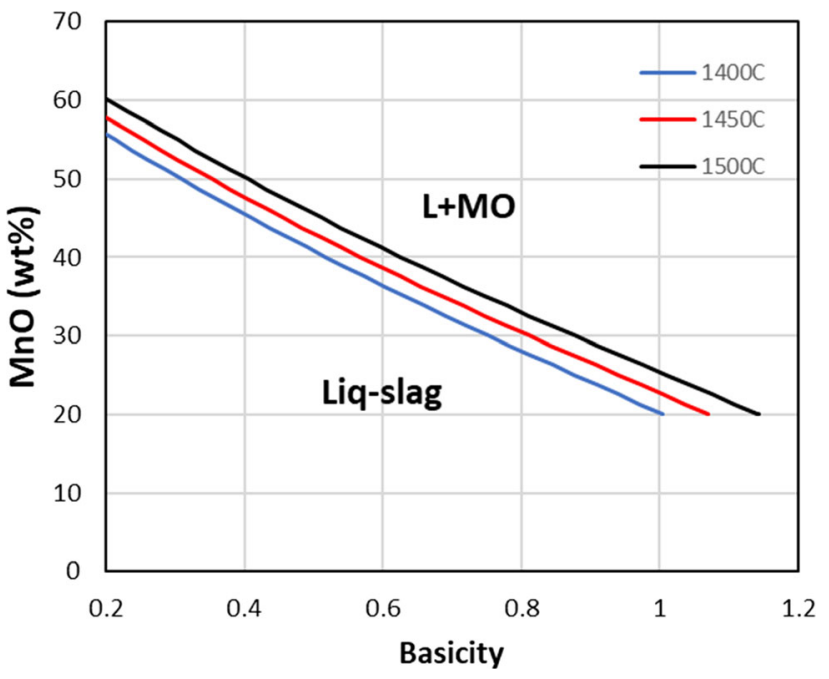

Fig. 8-Liquidus content of $\mathrm{MnO}$ vs. slag basicity in the $\mathrm{MnO}-\mathrm{SiO}_{2}-\mathrm{CaO}-\mathrm{Al}_{2} \mathrm{O}_{3}-5$ pct $\mathrm{MgO}\left(\mathrm{Al}_{2} \mathrm{O}_{3} / \mathrm{SiO}_{2}=0.57\right)$.

position. For quartz particles smaller than $2 \mathrm{~cm}$ it has been experimentally found that the quartz will dissolve in the Mn-source at temperatures less than 1400 ${ }^{\circ} \mathrm{C}$, and that the reduction will not occur until around $1500{ }^{\circ} \mathrm{C} \cdot{ }^{[32-35]}$ This step thus seems to hold for smaller quartz particles with good contact to the Mn-ore.

2. The reduction of Mn occurs from the partly molten Mn-source due to a slow quartz dissolution. The reduction of $\mathrm{Si}$ is thus determined by the quartz dissolution in the Mn-sources. Partly molten quartz has been found in the high temperature area in some industrial excavations, however it is rarely seen in pilot scale excavations. The dissolution of large quartz particles may hence be a larger problem for the electric current paths in the furnace, than for the average slag reduction.

As the effect of dissolution rate of quartz is yet not agreed upon, one can mention that Maroufi et al. ${ }^{[36]}$ investigated the quartz dissolution in a SiMn slag and found that the dissolution rate was determined by mass transfer of silica in the slag.

\section{B. High Temperature Thermodynamics}

The thermodynamics of the alloy-slag-gas-solid carbon system is investigated by a number of researchers like. ${ }^{[13,37-40]}$ In the following, FactSage will be used to highlight the main issues regarding the thermodynamics in the FeMn and SiMn process.

In the two-phase reaction area in Figure 14, it can also be seen that the higher basicity has a slightly lower reduction rate than the lower basicity slags. As a higher basicity will have more solid $\mathrm{MnO}$ phase, and hence a higher viscosity, the mass transport of $\mathrm{MnO}$ in the slag may be contributing to the reduced reaction rate. It was however concluded that the chemical reaction was rate determining reaction as no $\mathrm{MnO}$ gradients was found in the liquid phase in the slag. ${ }^{[13,44]}$ The effect on the reduction rate on the basicity is not yet fully understood. Both Ngoy ${ }^{[45]}$ and $\mathrm{Li}^{[46]}$ investigated Nchwaning and Comilog ores at various basicities from 0.04 to 1.3 by adding either quartz or lime to the ore. In the basicity area of $0.4-1$, the effect of basicity was not seen. It was however seen that Comilog was reduced much faster than Nchwaning ore, for all basicities, and hence it is believed that the reduction rate may also be affected by trace elements as seen also for the reduction of SiMn slags.

The metal produced in the FeMn process is typically 78 pct $\mathrm{Mn}, 7$ pct $\mathrm{C}$, less than 1 pct $\mathrm{Si}$ and the rest is iron, typically $\sim 14$ pct (ASTM, grade $\mathrm{B}^{[41]}$ ). The equilibrium constant for reaction [1] can be expressed by equation.[3]

$$
K=\frac{a_{\mathrm{Mn}} \cdot p_{\mathrm{CO}}}{a_{\mathrm{MnO}} \cdot a_{\mathrm{C}}}=\frac{a_{\mathrm{Mn}} \cdot p_{\mathrm{CO}}}{X_{\mathrm{MnO}} \cdot \gamma_{\mathrm{MnO}} \cdot a_{\mathrm{C}}}
$$

where $K$ is the equilibrium constant, $a_{\mathrm{Mn}}$ is the activity of $\mathrm{Mn}$ in the metal, $p_{\mathrm{CO}}$ is the partial pressure of $\mathrm{CO}$ in the gas phase, $a_{\mathrm{MnO}}$ is the activity of $\mathrm{MnO}$ in the slag, $a_{\mathrm{C}}$ is the activity of carbon, $X_{\mathrm{MnO}}$ is the mole fraction of $\mathrm{MnO}$ in slag and $\gamma_{\mathrm{MnO}}$ is the activity coefficient of $\mathrm{MnO}$ in the slag. As there is solid coke present, the activity of carbon is close to 1 . The partial pressure of $\mathrm{CO}$ in equilibrium with solid carbon above $1200{ }^{\circ} \mathrm{C}$ is also close to 1 , and as the metal composition is fixed at a fixed temperature, $a_{\mathrm{Mn}}$ is fixed. The amount of $\mathrm{MnO}$ in the slag can thus be determined by Eq. [4]. Evidently, the only variables affecting the $\mathrm{MnO}$ content in the slag is $\mathrm{K}$ and $\gamma_{\mathrm{MnO}}$.

$$
X_{\mathrm{MnO}}=\frac{1}{K} \cdot \frac{a_{\mathrm{Mn}}}{\gamma_{\mathrm{MnO}}}
$$




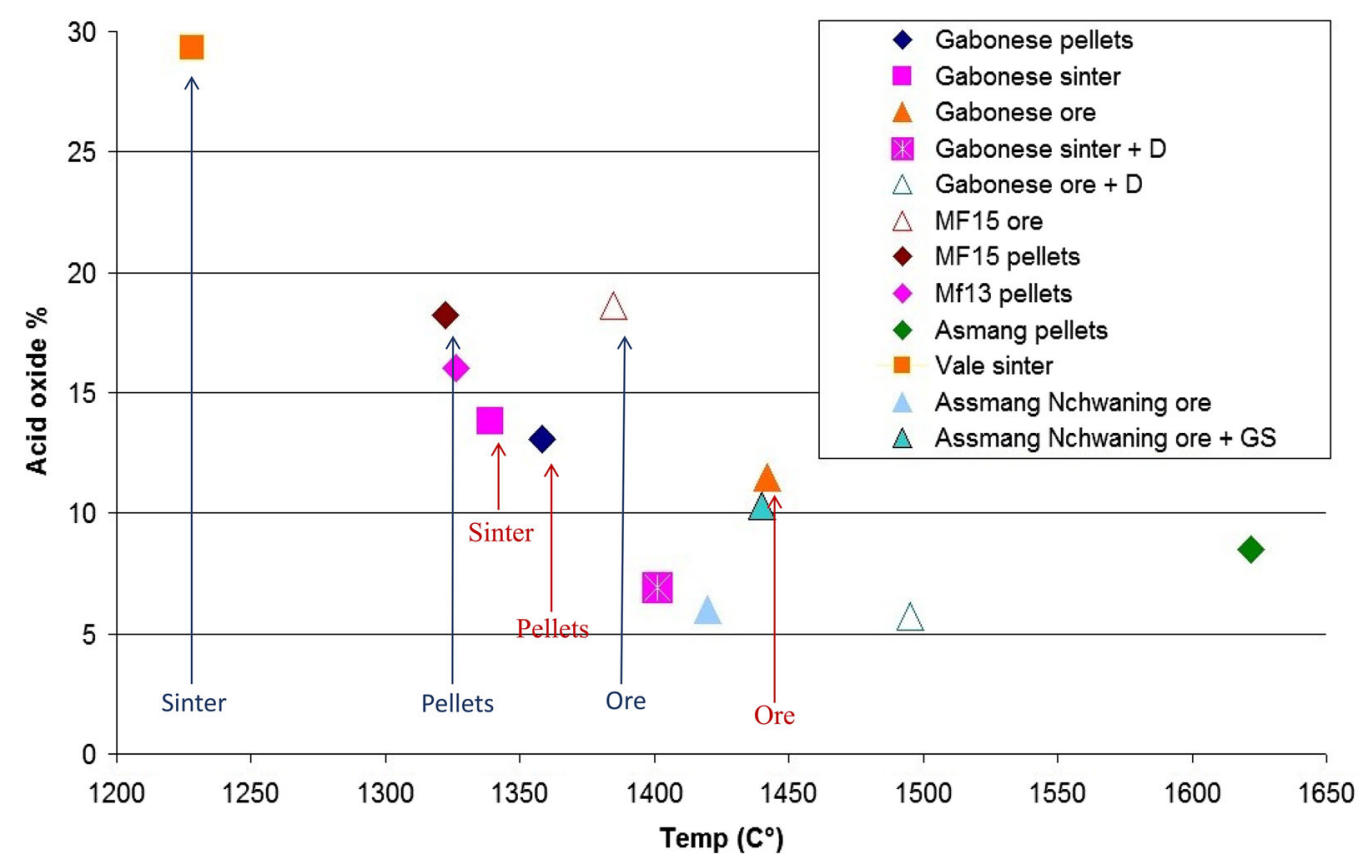

Fig. 9-Initial melting for various raw materials with various basicities and pre-treatment methods. Blue and red notation indicates the same ore with different pre-treatment (Color figure online) (adapted from Brynjulfsen 2013, ${ }^{[26]}$ Ringdalen $2015^{[28]}$ ).

The practical aspects of Eq. [4] is that the $\mathrm{MnO}$ content in the slag will be determined by temperature, mainly through the equlibrium constant, and the slag composition, through the activity coefficient. The equlibrium constant is, as seen in Figure 10, strongly dependent on temperature, and hence a lower $\mathrm{MnO}$ content will be achieved at higher temperatures. The activity coefficient of $\mathrm{MnO}$ will increase with the basic oxides $\mathrm{CaO}$ and $\mathrm{MgO}$, and decrease with the acid oxides $\mathrm{SiO}_{2}$ and $\mathrm{Al}_{2} \mathrm{O}_{3}$. According to Gibbs phase rule one can then determine the $\mathrm{MnO}$ content as a function of basicity and temperature when two variables are fixed like e.g., the $\mathrm{Al}_{2} \mathrm{O}_{3} / \mathrm{SiO} 2$ ratio and pct $\mathrm{MgO}$, as shown in Figure 11 for typical FeMn slags.

For SiMn slags, one needs to take into account reaction (2), that is the silicon distribution between the slag and the metal. Doing the same exercise as for the Mn distribution through Eqs. [5] and [6], it is seen that the silicon content in the metal is determined by the amount of $\mathrm{SiO}_{2}$ in the slag, the temperature $(f(T)$, mainly given by the equilibrium constant), the other slag constituents, and the metal composition $(h(m c))$ as shown in Eq. [7]. The metal composition, that is the $\mathrm{Mn} /$ Fe ratio is not affecting the silicon content in the same manner as temperature and slag composition. ${ }^{[1]}$ The correlation between the slag composition and temperature is shown in Figure 12. In order to obtain about 18 pct $\mathrm{Si}$ in the metal, the slag should be slightly below 40 pet $\mathrm{SiO}_{2}$ at $1600{ }^{\circ} \mathrm{C}$ for a $(\mathrm{CaO}+\mathrm{MgO}) / \mathrm{Al}_{2} \mathrm{O}_{3}$ ratio of 1 , which corresponding to most tapped slags. At low $\mathrm{Al}_{2} \mathrm{O}_{3}$ contents, i.e., a high $(\mathrm{CaO}+\mathrm{MgO}) / \mathrm{Al}_{2} \mathrm{O}_{3}$ ratio, a higher pct $\mathrm{SiO}_{2}$ is needed to compensate for the lack of acid components.

$$
\begin{gathered}
K=\frac{a_{\mathrm{Si}} \cdot p_{\mathrm{CO}}^{2}}{a_{\mathrm{SiO}_{2}} \cdot a_{\mathrm{C}}^{2}}=\frac{X_{\mathrm{Si}} \cdot \gamma_{\mathrm{Si}} \cdot p_{\mathrm{CO}}}{X_{\mathrm{SiO}_{2}} \cdot \gamma_{\mathrm{SiO}_{2}} \cdot a_{\mathrm{C}}} \\
X_{\mathrm{Si}}=X_{\mathrm{SiO}_{2}} \cdot K \cdot \gamma_{\mathrm{SiO}_{2}} \cdot \frac{1}{\gamma_{\mathrm{Si}}} \\
\text { Pct } \mathrm{Si}=p c t \mathrm{SiO}_{2} \cdot f(T) \cdot g\left(\frac{\mathrm{pct} \mathrm{CaO}+\text { pct } \mathrm{MgO}}{\mathrm{pct} \mathrm{Al}_{2} \mathrm{O}_{3}}\right) \\
\cdot h(\mathrm{mc})
\end{gathered}
$$

The function $f()$ describes the temperature-dependent part, $g()$ the slag composition and $h()$ the metal composition. The $\mathrm{MnO}$ content in equilibrium with SiMn alloys is relatively low, as seen in Figure 13, typically around 10 pet at $1600{ }^{\circ} \mathrm{C}$. This is quite low compared to what is typically tapped between $10-20 \mathrm{pct}$ as discussed above.

\section{Reaction Rates and Reduction Mechanism}

The reduction mechanisms for FeMn and SiMn are quite different, and will in this part be discussed separately. For industrial conditions in Submerged Arc Furnaces, Mn has not been seen to be reduced in solid state more than a couple of percentages. This indicates that the major part of the reduction is occurring in liquid state. As discussed above, and illustrated in Figure 3, it means for FeMn primary slags, that the reduction will initiate in the two phase area of liquid phase and a solid $\mathrm{MnO}$-phase. SiMn primary slag will 


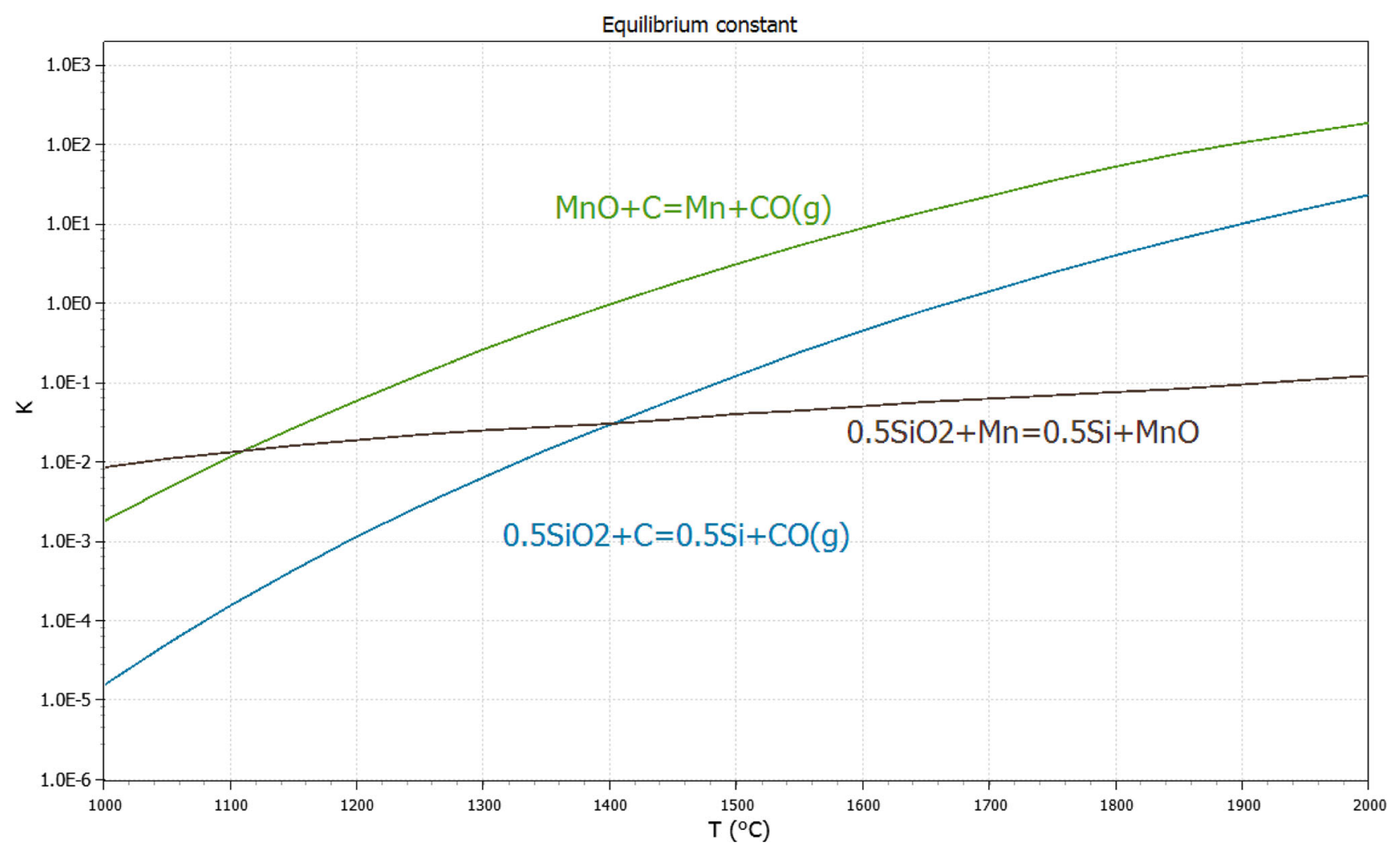

Fig. 10 -Equilibrium constant of $\mathrm{MnO}$ and $\mathrm{SiO}_{2}$ reduction according to reactions (1) and (2) (calculated from HSC Chemistry v.10).

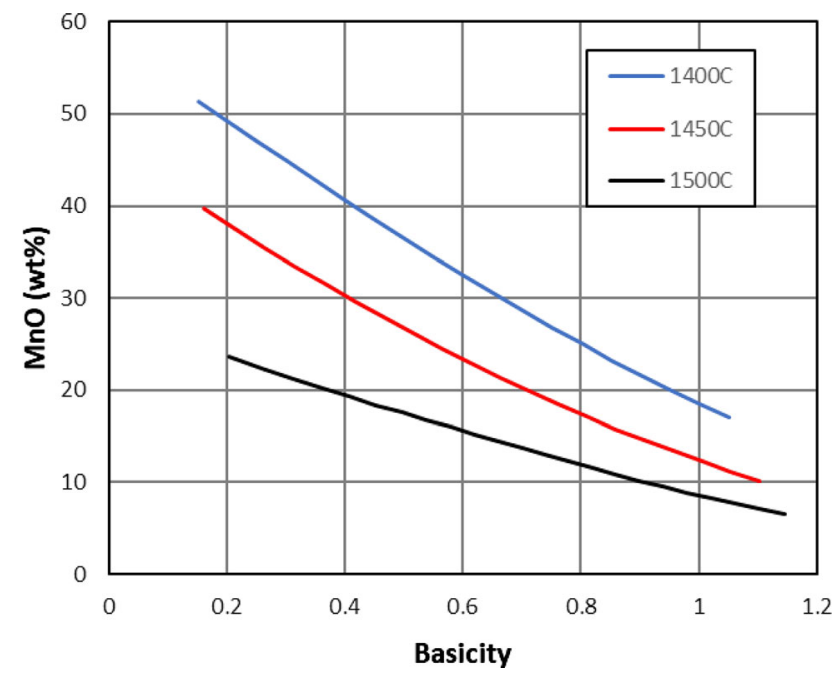

Fig. $11-\mathrm{MnO}$ content vs. basicity for a $\mathrm{Al}_{2} \mathrm{O}_{3} / \mathrm{SiO}_{2}$ ratio of 0.57 with 5 pet $\mathrm{MgO}$ in equilibrium with a $\mathrm{FeMn}$ where the $\mathrm{Mn} / \mathrm{Fe}$ ratio is 7.8 .

probably be all liquid when the reduction starts. The mechanism during reduction will hence be affected by the phases in the primary slag.

The kinetics of a FeMn slag is described by a rapid reaction when the activity of $\mathrm{MnO}$ is high and close to 1 (above the liquidus composition) followed by a slow reaction step below the liquidus composition as the

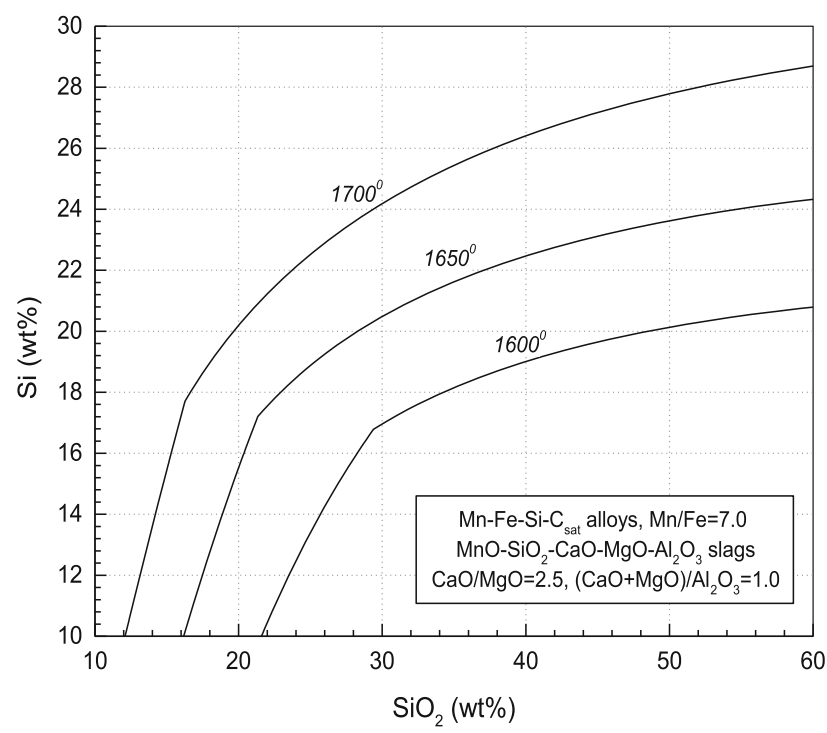

Fig. 12-Pct $\mathrm{Si}$ in the metal as a function of pet $\mathrm{SiO}_{2}$ and temperature (for a fixed slag and metal composition) ${ }^{[1]}$. (Figure is reprinted with permission from Ref. 1).

activity of $\mathrm{MnO}$ is drastically reduced, as shown in Figure 14. This is since the reaction rate will follow the activity of $\mathrm{MnO}$ according to reaction (8).

$$
\frac{\mathrm{d} \mathrm{Pct} \mathrm{MnO}}{\mathrm{d} t}=A \cdot k \cdot\left(a_{\mathrm{MnO}}-a_{\mathrm{MnO}(\text { eq. })}\right)
$$



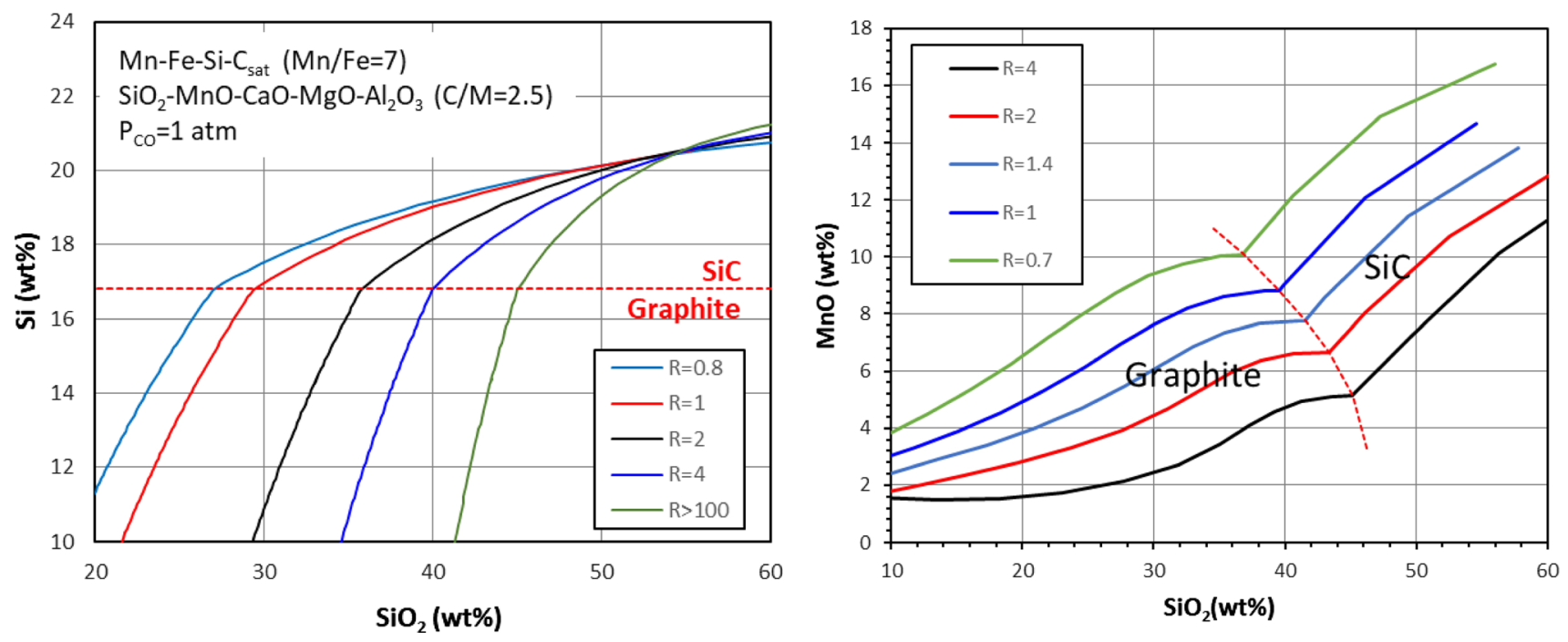

Fig. 13 - Pct $\mathrm{Si}$ in the metal and wt pct $\mathrm{MnO}$ in the slag as a function of slag composition for SiMn slags at $1600{ }^{\circ} \mathrm{C}$. Slag composition is given by $\mathrm{R}=(\mathrm{CaO}+\mathrm{MgO}) / \mathrm{Al}_{2} \mathrm{O}_{3}$.
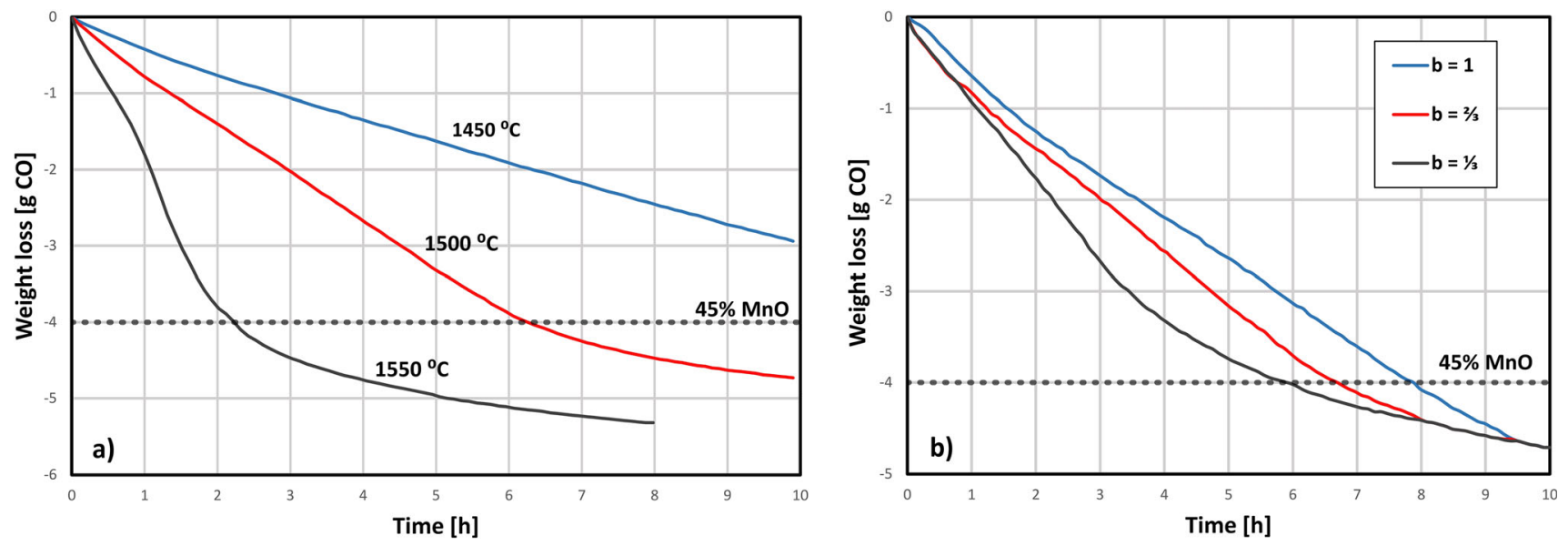

Fig. 14-Weight loss, representing the reaction rate of reaction (1) from 72 to 73 pct $\mathrm{MnO}$ with $(a) \mathrm{Al}_{2} \mathrm{O}_{3} / \mathrm{SiO}_{2}$ ratio of 0.25 and basicity of 0.67 and $(b)$ at $1500{ }^{\circ} \mathrm{C}$ and $\mathrm{Al}_{2} \mathrm{O}_{3} / \mathrm{SiO}_{2}$ ratio of 0.5 (adapted from Ref. 40 ).

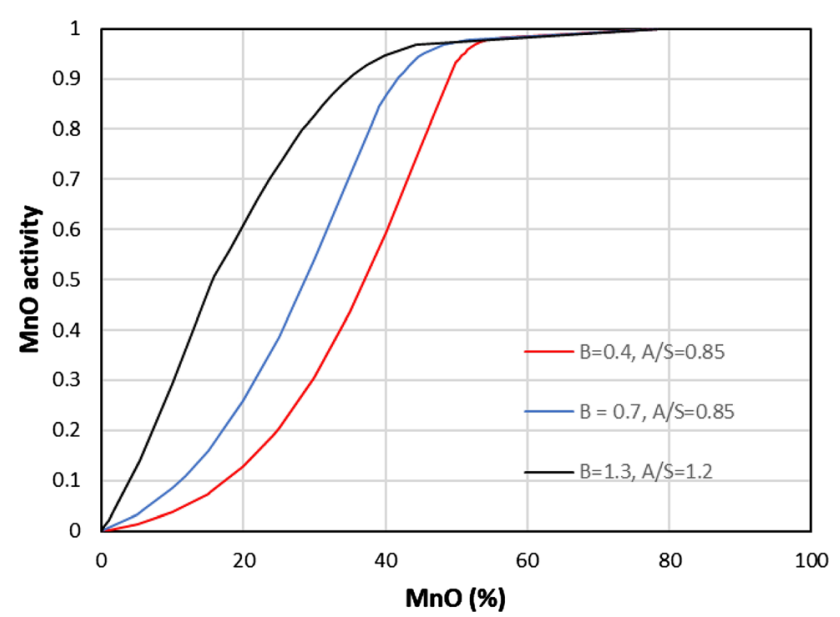

Fig. 15- $\mathrm{MnO}$ activity as a function of pet $\mathrm{MnO}$ at various basicities and $\mathrm{Al}_{2} \mathrm{O}_{3} / \mathrm{SiO}_{2}$ ratios at $1500{ }^{\circ} \mathrm{C}$. where $k$ is rate constant and $\mathrm{A}$ is the reaction area between the slag and the carbon material. ${ }^{[13,30,42]}$ When the solid $\mathrm{MnO}$ phase is in equilibrium with the liquid slag, the activity of $\mathrm{MnO}$ is close to 1 . Less than $20 \mathrm{pct}$ $\mathrm{MgO}$ has been found to be present in the solid $\mathrm{MnO}$ phase ${ }^{[13]}$ and according to Geldenhuis 43 , the $\mathrm{MnO}$ activity in an $\mathrm{MnO}-\mathrm{MgO}$ solid solution are ideal in this area. The activity will hence be high in the two-phase area, and when reaching the one phase liquid area, the reduction rate will decrease due to lower $\mathrm{MnO}$ activity. The $\mathrm{MnO}$ activity in the two and one phase area is shown in Figure 15.

The kinetics for the reduction of SiMn-slag is quite different. The reduction will occur while the slag is in liquid state above $1500{ }^{\circ} \mathrm{C}$, above liquidus composition. It has previously been observed that sulfur in small amounts would increase the reaction rate, corresponding to iron in the metal. ${ }^{[47,48]}$ This was in the later years verified by Referencs 32, 33, 49 through 51 . The reaction rate will be very different when sulfur is present, as 

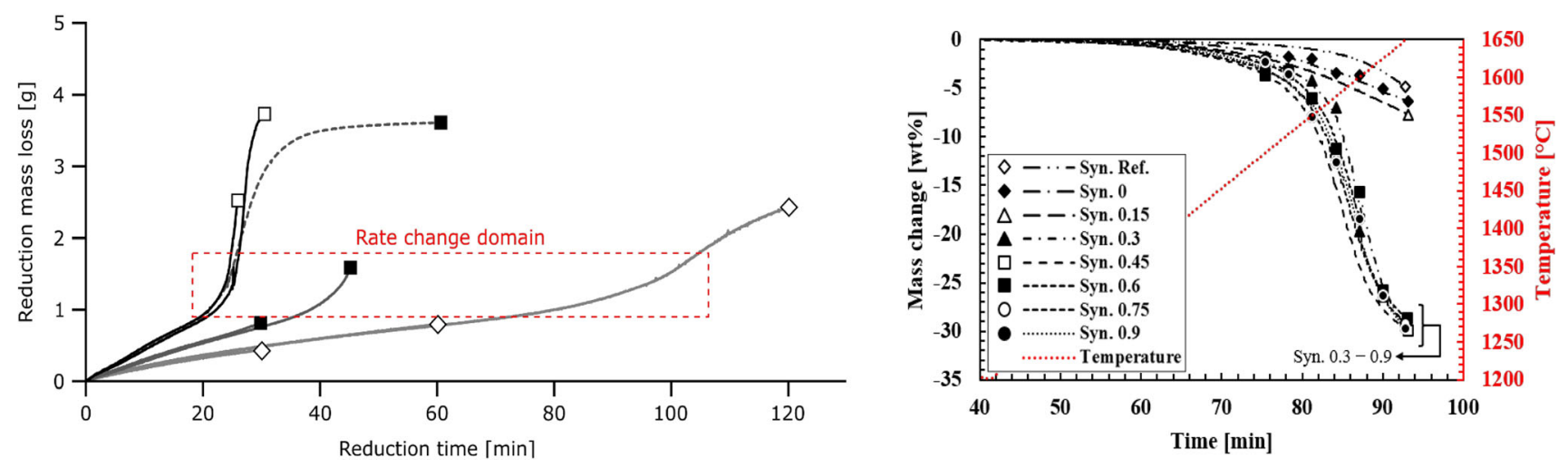

Fig. 16-Reduction rate of primary SiMn slag based on Assmang ore at 1540,1610 and $1660^{\circ} \mathrm{C}$ (left figure) ${ }^{[50]}$ and the reduction rate with varying $\mathrm{S}$ content (right figure), given as wt pct in the figure, at non-isothermal conditions. ${ }^{[5]}$

shown in the work from Tranell 52 and Hosum 53, where it was seen that the reaction rate was faster with charcoal compared to coke, when 0.3 pct $S$ was present in the slag. When no slag was present, the coke would give a higher reaction rate, probably because of the high inherent $\mathrm{S}$ content in the coke.

In the SiMn reaction, the slag will initially react with a slow reduction step, followed by a fast reduction step as shown in Figure 16. Foaming has been observed in the slag after the initial step ${ }^{[33,50,53,54]}$ and hence both a larger reduction area towards the coke as well as convection in the slag phase may increase the reduction rate. When enough sulfur was present $(\sim 0.3$ pct $S)$ it is seen that the first slow step, would hardly be present, and that the reduction would only go through the fast second step. The reaction rate for both $\mathrm{MnO}$ and $\mathrm{SiO}_{2}$ can be calculated based on reaction $(8) .{ }^{[50,55]}$

\section{FUNDAMENTAL SLAG PROPERTIES IN THE FIVE COMPONENT MNO, MGO, CAO, $\mathrm{SIO}_{2}, \mathrm{AL}_{2} \mathrm{O}_{3}$ SYSTEM}

Numerous slag properties that are important for the $\mathrm{Mn}$-ferroalloy productionare reviewed in this part of the paper. Specifically the slag structure, viscosity, density, surface- and interfacial tension and the electrical conductivity of the five-component slag system will be considered.

\section{A. Slag Structure}

The structure of silicate melts is of fundamental importance in metallurgical processes because the melt structure is closely linked to transport properties such as viscosity, density, and electrical conductivity. ${ }^{[56,57]}$ The degree of polymerization (DOP) of silicate networks has been introduced as the most influential parameter for linking these properties and slag structure. DOP and viscosity are proportional, while density and electrical conductivities are inversely proportional to DOP. ${ }^{[58,59]}$ In silicate slags, the presence of network-former and network-modifier elements determines the DOP of the silicate structure. $\mathrm{SiO}_{2}$ is among the network-former oxides, while alkali and alkali-earth oxides, such as $\mathrm{Na}_{2} \mathrm{O}$ and $\mathrm{CaO}$ (basic oxides), contribute to depolymerization of the silicate network as network-modifying components. Amphoteric oxides, such as $\mathrm{Al}_{2} \mathrm{O}_{3}$, can act as either network-former or network-modifier oxide based on the availability of basic oxides in the silicate network. $^{[60]}$

Other important parameters are oxygens species, namely bridging oxygen $\left(\mathrm{O}^{0}\right)$, non-bridging oxygen $\left(\mathrm{O}^{-}\right)$, and free oxygen $\left(\mathrm{O}^{2-}\right)$. In silicate networks, $\mathrm{O}^{0}$ is connected to two network-former cations $\left(\mathrm{Si}-\mathrm{O}^{0}-\mathrm{Si}\right.$ or $\left.\mathrm{Si}-\mathrm{O}^{0}-\mathrm{Al}\right), \mathrm{O}^{-}$is bounded to only one network-former cations $\left(\mathrm{Ca}-\mathrm{O}^{-}-\mathrm{Si}\right)$, while $\mathrm{O}^{2-}$ is connected to only network-modifier cations $\left(\mathrm{Ca}-\mathrm{O}^{2-}-\mathrm{Ca}\right)$. By increasing $\mathrm{O}^{2-}$ through dissociation of basic oxides, the DOP of silicate networks decrease because $\mathrm{O}^{2-}$ reacts with $\mathrm{O}^{0}$ in the silicates to split the highly complex structures of $\mathrm{Si}-\mathrm{O}$ into low polymerized units. There are various types of $\mathrm{Si}-\mathrm{O}$ units called $Q^{n}$ species where $\mathrm{n}$ is the number of $\mathrm{O}^{0}$ in the unit and can be 0 to 4 . These units are monomer structure $\left(Q^{0}\right)$, dimer structure $\left(Q^{1}\right)$, chain structure $\left(Q^{2}\right)$, sheet structure $\left(Q^{3}\right)$, and 3-dimensional structure $\left(Q^{4}\right) .{ }^{[61]}$ The DOP parameter can be found both experimentally and theoretically through $Q^{n}$ species obtained by Raman analysis and slag compositions, respectively. Oxygens species are also given experimentally using X-ray photoelectron spectroscopy (XPS) and theoretically using slag compositions. ${ }^{[62]}$

Raman spectroscopy has been employed to obtain information on the structural properties of various slags. So far, extensive research has been conducted on the silicate systems using Raman spectroscopy technique including the influence of basic and amphoteric oxides on the silicate structures. ${ }^{[61]}$

Although the five-component slag system MnO$\mathrm{SiO}_{2}-\mathrm{CaO}-\mathrm{MgO}-\mathrm{Al}_{2} \mathrm{O}_{3}$ has not been studied through Raman spectroscopic yet, there are several studies that have investigated slags containing $\mathrm{MnO}$ using Raman analysis. ${ }^{[58,59,63-66]}$ Slag structure has been reported for the ternary systems of $\mathrm{CaO}-\mathrm{SiO}_{2}-\mathrm{MnO}^{[58,59,63]}$ and $\mathrm{MnO}-\mathrm{SiO}_{2}-\mathrm{Al}_{2} \mathrm{O}_{3}{ }^{[66]}$ as well as the quaternary systems of $\mathrm{CaO}-\mathrm{SiO}_{2}-\mathrm{MnO}-x \mathrm{CaF}_{2}[x=0.0$ to $14.5 \mathrm{wt} \mathrm{pct}],{ }^{[63]}$ 


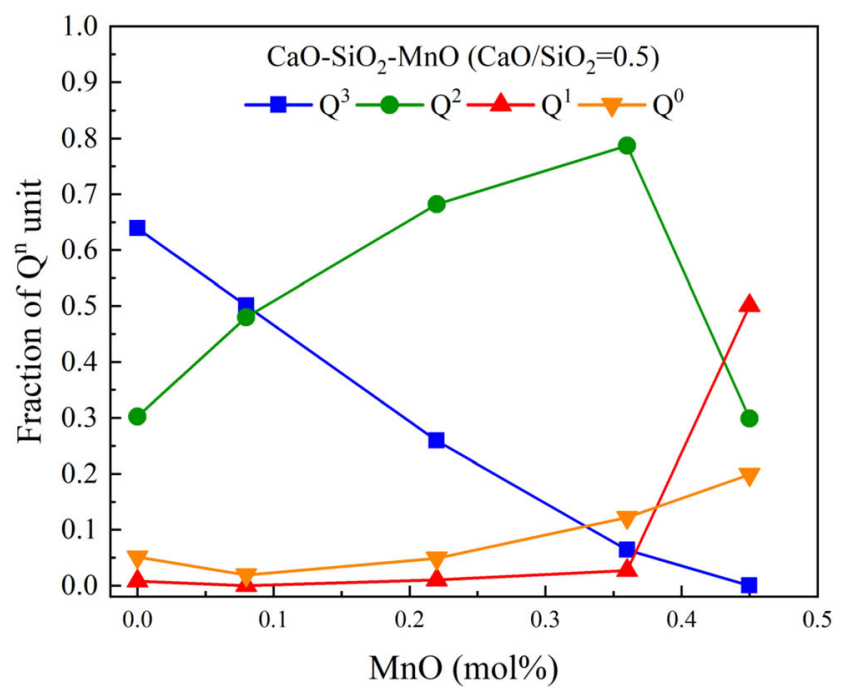

(a)

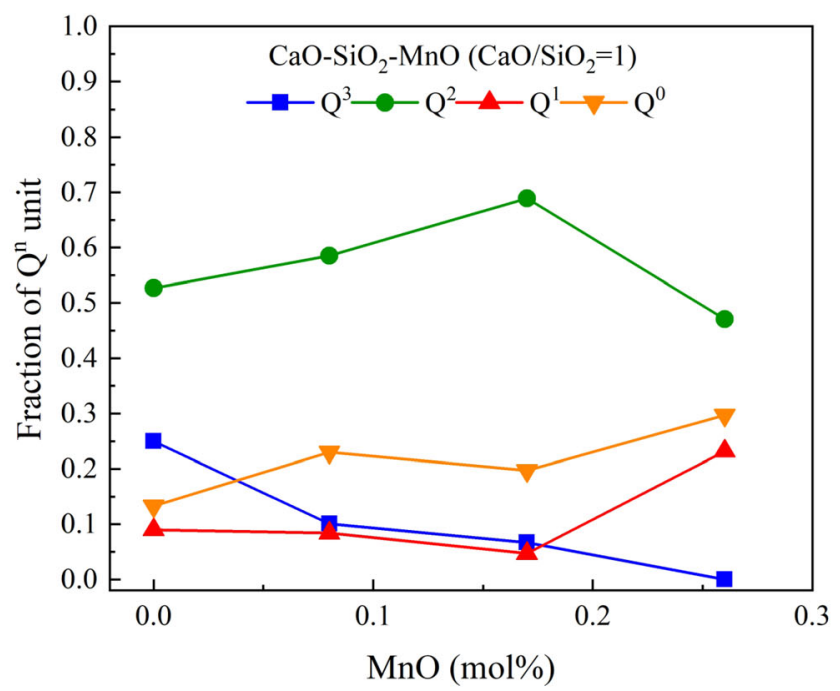

(b)

Fig. 17-Fraction of $\mathrm{Q}^{\mathrm{n}}$ units vs. the $\mathrm{MnO}$ (mol pct) content. (a) the $\mathrm{CaO}-\mathrm{SiO}_{2}-\mathrm{MnO}\left(\mathrm{CaO} / \mathrm{SiO}_{2}=0.5\right)$ system and $(b)$ the $\mathrm{CaO}-\mathrm{SiO}{ }_{2}-\mathrm{MnO}$ $\left(\mathrm{CaO} / \mathrm{SiO}_{2}=1\right)$ system (data from Ref. 58).

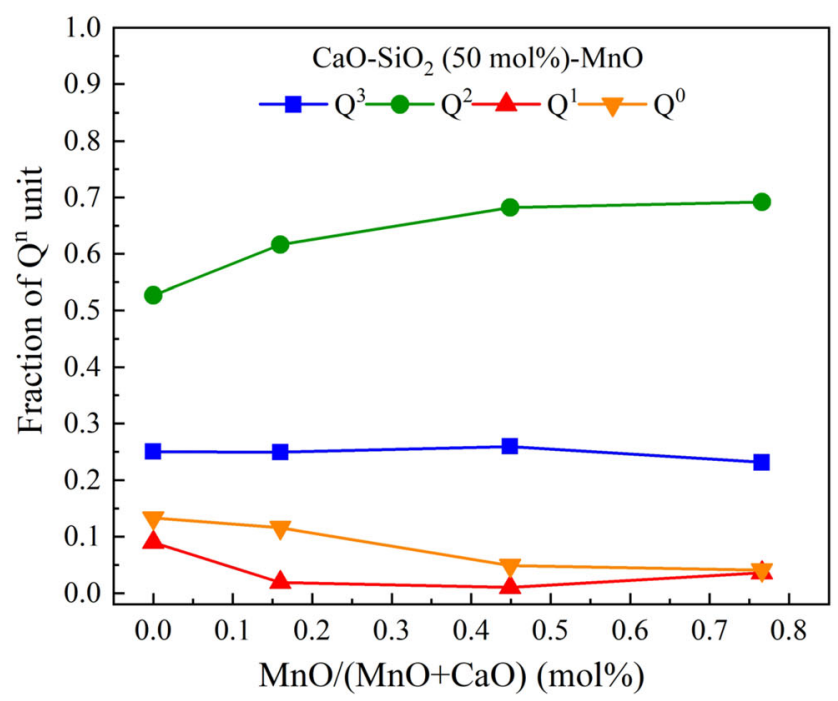

(a)

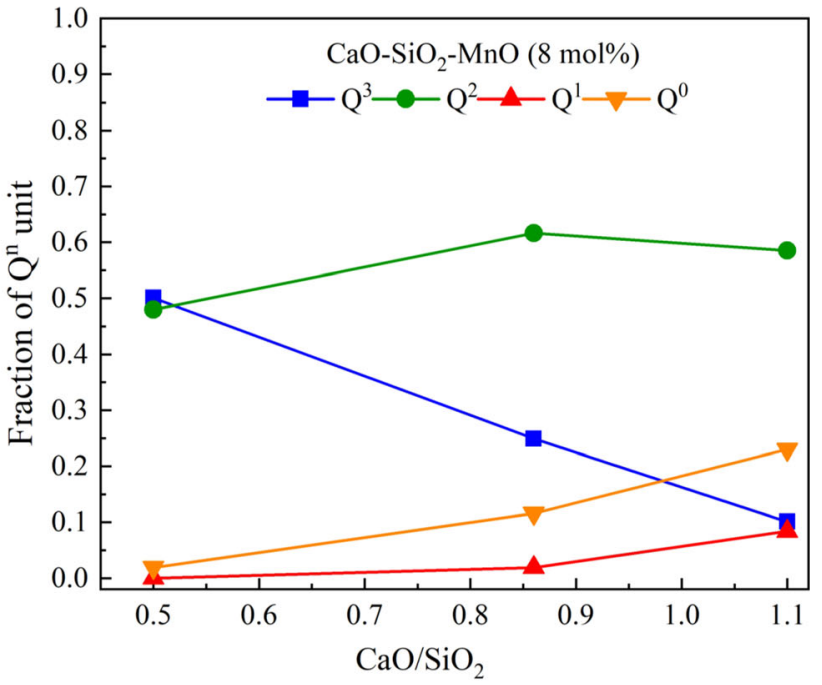

(b)

Fig. 18- (a) Fraction of $\mathrm{Q}^{\mathrm{n}}$ units $v$ s. the $\mathrm{MnO} /(\mathrm{MnO}+\mathrm{CaO})\left(\mathrm{mol}\right.$ pct) content in the $\mathrm{CaO}^{-\mathrm{SiO}_{2}}\left(50 \mathrm{~mol}\right.$ pct)- $\mathrm{MnO}$. (b) Fraction of $\mathrm{Q}^{\mathrm{n}}$ units $v$ s. the $\mathrm{CaO} / \mathrm{SiO}_{2}$ (mol pct) content in the $\mathrm{CaO}-\mathrm{SiO} 2-\mathrm{MnO}$ (8 mol pct) (data from Ref. 58).

$\mathrm{TiO}_{2}-\mathrm{MnO}$ (30 wt pet)- $\mathrm{SiO}_{2}-\mathrm{Al}_{2} \mathrm{O}_{3},{ }^{[64]} \mathrm{MO}-\mathrm{SiO}_{2}-\mathrm{MnO}-$ $y \mathrm{CaF}_{2}\left[\mathrm{M}(=\mathrm{Ca}\right.$ or $\mathrm{Ba}) \mathrm{O}, y=0$ to $15 \mathrm{~mol} \mathrm{pct]}{ }^{[65]}$ and $\mathrm{MnO}-\mathrm{SiO}_{2}-\mathrm{Al}_{2} \mathrm{O}_{3}-\mathrm{ZCe}_{2} \mathrm{O}_{3}[z=0.0$ to $5.6 \mathrm{~mol} \mathrm{pct}] .{ }^{[66]}$

Park $^{[58]}$ studied the structure of the $\mathrm{CaO}-\mathrm{SiO}_{2}-\mathrm{MnO}$ system using micro-Raman spectroscopic analysis quantitively. In this slag system, $\mathrm{CaO}, \mathrm{SiO}_{2}$, and $\mathrm{MnO}$ were varied from 0 to $52 \mathrm{~mol} \mathrm{pct,} 36$ to $63 \mathrm{~mol} \mathrm{pct}$, and 0 to $58 \mathrm{~mol}$ pct, respectively. The compositions containing around 10 to 20 and 40 to $50 \mathrm{~mol}$ pet $\mathrm{MnO}$ can be considered as simpler representatives of $\mathrm{SiMn}$ and FeMn slags, respectively. The variations of $Q^{n}\left(Q^{0}\right.$ to $\left.Q^{3}\right)$ species were investigated with respect to $\mathrm{MnO}$ content, the substitution of $\mathrm{CaO}$ with $\mathrm{MnO}$, and the ratio of $\mathrm{CaO}$ to $\mathrm{SiO}_{2}$.
The influence of $\mathrm{MnO}$ addition was investigated for the $\mathrm{CaO}-\mathrm{SiO}_{2}-\mathrm{MnO}$ system at $\mathrm{CaO} / \mathrm{SiO}_{2}$ equal to 0.5 and 1.1 as shown in Figures 17(a) and (b), respectively. For both ratios of $\mathrm{CaO} / \mathrm{SiO}_{2}$, the variations of $Q^{0}$ to $Q^{3}$ showed similar behavior of increasing $\mathrm{MnO}$. The $Q^{3}$ unit reduced and the fractions of $Q^{1}$ and $Q^{0}$ units increased continuously, while the fraction of $Q^{2}$ illustrated a maximum at around $\mathrm{SiO}_{2} 40 \mathrm{~mol}$ pct.

Figure 18(a) presents the fractions of $Q^{n}$ units with respect to the $\mathrm{MnO} /(\mathrm{MnO}+\mathrm{CaO})$ changes in the $\mathrm{CaO}-\mathrm{SiO}_{2}(\sim 50 \mathrm{~mol} \mathrm{pct})-\mathrm{MnO}$ system. By the substitution of $\mathrm{CaO}$ by $\mathrm{MnO}$, the Raman analysis found that the $Q^{3}$ unit slightly decreased while the $Q^{2}$ unit increased. The fractions of $Q^{1}$ and $Q^{0}$ units were slightly reduced by increasing $\mathrm{MnO} /(\mathrm{MnO}+\mathrm{CaO})$. The effect of 
$\mathrm{CaO} / \mathrm{SiO}_{2}$ changes on the slag structure was studied in the $\mathrm{CaO}-\mathrm{SiO}_{2}-\mathrm{MnO}$ (8 mol pct) system. Figure 18(b) displays the fractions of $Q^{n}$ units vs. increasing $\mathrm{CaO} /$ $\mathrm{SiO}_{2}$. The fraction of $\mathrm{Q}^{3}$ unit was reduced while the fractions of $Q^{1}$ and $Q^{0}$ units were increased by increasing $\mathrm{CaO} / \mathrm{SiO}_{2}$ from 0.5 to 1.1 , demonstrating that the depolymerization of the silicate network (or reducing DOP of the silicate structure) as the ratio of $\mathrm{CaO}$ to $\mathrm{SiO}_{2}$ was increased at a fixed $\mathrm{MnO}$ content.

In this study, the $Q^{3} / Q^{2}$ ratio was proposed for determining DOP of the silicate network. The results shown in Figures 17 and 18 indicate that $\mathrm{MnO}$ is a network-modifier element in the silicate systems similarly to $\mathrm{CaO}$, because the $Q^{3} / Q^{2}$ ratio reduced by increasing the $\mathrm{MnO}$ content, thereby the silicate network was depolymerized. Also, a linear correlation between $\ln \left(Q^{3} / Q^{2}\right)$ and viscosity, density, and electrical conductivity were explored, demonstrating the influence of slag structure (DOP of the slag network) on these slag properties. It was found that $\log$ viscosity increases linearly by increasing $\ln \left(Q^{3} / Q^{2}\right)$ while $\log$ density and $\log$ electrical conductivity reduce with increasing $\ln \left(Q^{3}\right)$ $Q^{2}$ ) linearly. ${ }^{[58]}$

\section{B. Slag Viscosity}

The viscosity of slag contributes to the metal-slag separation efficiency and tapping process, and is thus closely related to operation efficiency and minimizing the energy usage. ${ }^{[67]}$ Slag viscosity depends on temperature and slag composition as the viscosity decreases with increasing temperature and basic oxide contents.

Viscosity measurements for the slag system MnO$\mathrm{SiO}_{2}-\mathrm{CaO}-\mathrm{MgO}-\mathrm{Al}_{2} \mathrm{O}_{3}$ have been carried out for various industrial applications. ${ }^{[68-71]} \mathrm{A}$ wide variation of slag compositions has been investigated which were close to slags in Mn-ferroalloy production in the submerged arc furnace. In addition to $\mathrm{MnO}-\mathrm{SiO}_{2}-$ $\mathrm{CaO}-\mathrm{MgO}-\mathrm{Al}_{2} \mathrm{O}_{3}$, viscosity has been measured for its various subsystems such as the binary $\mathrm{MnO}-\mathrm{SiO}_{2}$ system, ${ }^{[72,73]}$ the ternary systems of $\mathrm{MnO}^{-\mathrm{SiO}_{2}-}$ $\mathrm{CaO}{ }^{[72,74,75]}$ and $\mathrm{MnO}-\mathrm{SiO}_{2}-\mathrm{Al}_{2} \mathrm{O}_{3}{ }^{[73]}$ as well as the quaternary systems of $\mathrm{MnO}-\mathrm{SiO}_{2}-\mathrm{CaO}-\mathrm{MgO}^{[76]}$ and $\mathrm{MnO}-\mathrm{SiO}_{2}-\mathrm{CaO}-\mathrm{Al}_{2} \mathrm{O}_{3}{ }^{[68,77]}$ In general, the results of these investigations have revealed the effect of both temperature and $\mathrm{MnO}$ content. These findings suggest that slag viscosity decreases by increasing temperature and reduces by increasing the $\mathrm{MnO}$ content. The latter can be understood by considering the fact that $\mathrm{MnO}$ is a basic oxide and acts as a network breaker in the silicate network. In the following, some of the results and observations will be reviewed in more detail.

Viscosity measurements for $\mathrm{MnO}-\mathrm{SiO}_{2}-\mathrm{CaO}$ have been performed for a wide variety of compositions. In Segers et al. study, ${ }^{[72]}$ the $\mathrm{SiO}_{2}$ content was given as 32 to 50 wt pct while the contents of $\mathrm{MnO}$ and $\mathrm{CaO}$ were varied from 10 to 64 and 0 to $45 \mathrm{wt}$ pct, respectively. The measurements were carried out at $1500{ }^{\circ} \mathrm{C}$ and illustrated the effect of $\mathrm{SiO}_{2}$ and the substitution of $\mathrm{CaO}$ by $\mathrm{MnO}$. In Ji's (2001) work, ${ }^{[75]} \mathrm{SiO}_{2}, \mathrm{MnO}$, and $\mathrm{CaO}$ were changed from 33 to $50 \mathrm{wt}$ pct, 15 to $56 \mathrm{wt}$ pct, and

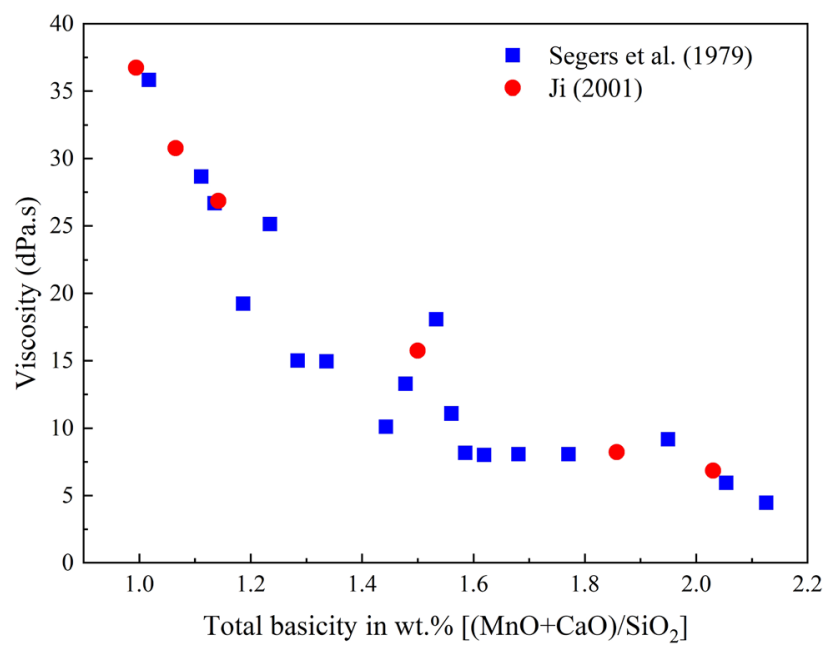

Fig. 19-Experimental viscosities (dPa.s) with respect to total basicity (wt pet) for the $\mathrm{MnO}-\mathrm{SiO}_{2}-\mathrm{CaO}$ system. Comparing results from Segers et al. ${ }^{72}$ at $1500{ }^{\circ} \mathrm{C}$ and $\mathrm{Ji}^{75}$ at $1480{ }^{\circ} \mathrm{C}$.

8 to 45 wt pct. The viscosity measurements were reported for the temperature range from $1300^{\circ} \mathrm{C}$ to $1480{ }^{\circ} \mathrm{C}$. In Figure 19, the viscosity (dPa.s) is plotted as a function of the slag basicity (wt pct) introduced as $(\mathrm{MnO}+\mathrm{CaO}) / \mathrm{SiO}_{2}$ for the $\mathrm{MnO}-\mathrm{SiO}_{2}-\mathrm{CaO}$ system to compare the results found by Segers et al..$^{[72]}$ at $1500{ }^{\circ} \mathrm{C}$ and $\mathrm{Ji}^{75}$ at $1480^{\circ} \mathrm{C}$. As seen, the viscosity results of these two studies display the same trend, revealing that the viscosity reduces with increasing the basicity through increasing the basic oxides, namely $\mathrm{MnO}$ and $\mathrm{CaO}$.

Woollacott et al ${ }^{69}$ reported the experimental viscosities at $1500{ }^{\circ} \mathrm{C}$ for a group of $\mathrm{MnO}-\mathrm{SiO}_{2}-\mathrm{CaO}-$ $\mathrm{MgO}-\mathrm{Al}_{2} \mathrm{O}_{3}$ compositions related to slags in the production of high-carbon ferromanganese alloys. The $\mathrm{MnO}$ and $\mathrm{SiO}_{2}$ contents were changed from 7 to 35 and 27 to $37 \mathrm{~mol}$ pct, respectively. $\mathrm{Al}_{2} \mathrm{O}_{3}$ was fixed at 10 mol pct, $\mathrm{CaO}$ and $\mathrm{MgO}$ were varied from 13 to 45 mol pct and 6 to $21 \mathrm{~mol}$ pct, respectively. It was found that $\mathrm{SiO}_{2}$ content induces the major effect on viscosity. While an increase in the $\mathrm{SiO}_{2}$ content increased the viscosity, $\mathrm{MnO}$ proved the strongest ability for reducing the viscosity among the involved basic oxides in the slag systems.

In another study published by Persson ${ }^{70}$ for slags associated with Mn-ferroalloy production in the submerged arc furnace, viscosity measurements were carried out within four groups of synthetic slags (called Slag A, B, C, and D) over wide composition ranges as presented in Table III. Each group includes compositions containing 30,40 , and 50 wt pet $\mathrm{MnO}$, while $\mathrm{SiO}_{2}$ and $\mathrm{Al}_{2} \mathrm{O}_{3}$ were varied from 14 to 33 and 8 to $33 \mathrm{wt}$ pet respectively. $\mathrm{CaO}$ and $\mathrm{MgO}$ as basic oxides in the slag systems were changed from 4 to 29 and 0.3 to $7 \mathrm{wt}$ pct, respectively. Table III displays the lower and higher measured temperatures which were limited by the presence of $\mathrm{MnO}$ precipitates and the use of alumina tube in the viscometer apparatus, respectively. The viscosities were measured over the temperature range from $1265{ }^{\circ} \mathrm{C}$ to $1712{ }^{\circ} \mathrm{C}$ where this range was varied based on the compositions. 
Table III. Compositions (Wt Pet), Viscosity Measurements (dPa.s), and Temperature Ranges $\left({ }^{\circ} \mathrm{C}\right.$ ) for Four Groups of Slags Associated With Mn-Ferroalloy Production (Data from Ref. 70)

\begin{tabular}{|c|c|c|c|c|c|c|c|}
\hline Slag name & $\mathrm{MnO}$ & $\mathrm{SiO}_{2}$ & $\mathrm{CaO}$ & $\mathrm{Al}_{2} \mathrm{O}_{3}$ & $\mathrm{MgO}$ & Viscosity (dPa.s) & Temperature $\left({ }^{\circ} \mathrm{C}\right)$ \\
\hline A 50 & 51.08 & 20.8 & 15.04 & 9.49 & 4.39 & $0.29-2.50$ & $1321-1703$ \\
\hline A 40 & 40.8 & 25.29 & 18.21 & 11.34 & 5.25 & $0.38-2.86$ & $1277-1706$ \\
\hline A 30 & 30.61 & 29.58 & 21.36 & 13.14 & 6.12 & $0.50-7.46$ & $1265-1698$ \\
\hline $\mathrm{B} 50$ & 50.69 & 14.38 & 10.63 & 24.65 & 0.35 & $0.34-4.48$ & $1275-1696$ \\
\hline B40 & 40.49 & 17.34 & 12.76 & 29.84 & 0.36 & $0.42-3.10$ & $1355-1703$ \\
\hline B30 & 31.47 & 20.19 & 14.99 & 33.15 & 0.62 & $0.66-4.55$ & $1430-1712$ \\
\hline $\mathrm{C} 50$ & 49.44 & 22.02 & 3.69 & 23.82 & 1.51 & $0.41-7.51$ & $1284-1710$ \\
\hline $\mathrm{C} 40$ & 39.96 & 27.2 & 4.49 & 27.33 & 1.83 & $0.77-6.47$ & $1333-1703$ \\
\hline $\mathrm{C} 30$ & 31.96 & 32.65 & 4.87 & 28.86 & 2.15 & $1.02-10.90$ & $1368-1699$ \\
\hline D50 & 50.84 & 15.62 & 21.13 & 8.09 & 4.94 & $0.23-0.56$ & $1617-1695$ \\
\hline D40 & 40.62 & 19.44 & 25.43 & 9.66 & 6 & $0.22-0.44$ & $1449-1704$ \\
\hline D30 & 32.14 & 22.07 & 28.69 & 11.44 & 6.65 & $0.31-0.65$ & $1486-1694$ \\
\hline
\end{tabular}
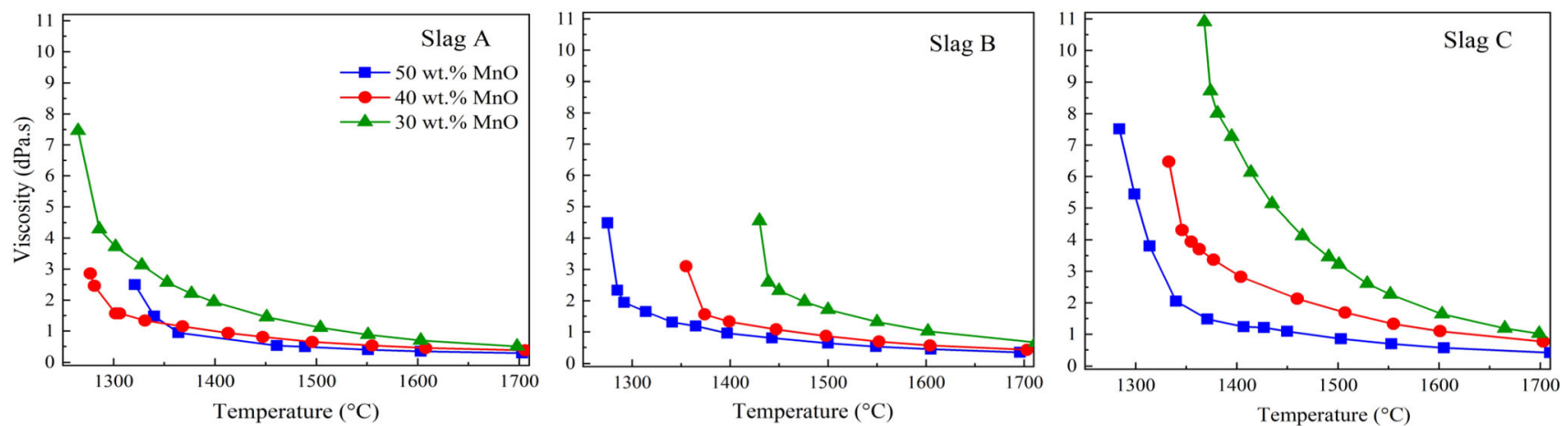

Fig. 20 - Viscosity measurements (dPa.s) vs. temperature $\left({ }^{\circ} \mathrm{C}\right)$ for Slag A, B, C, presented in Persson. ${ }^{\text {[70] }}$

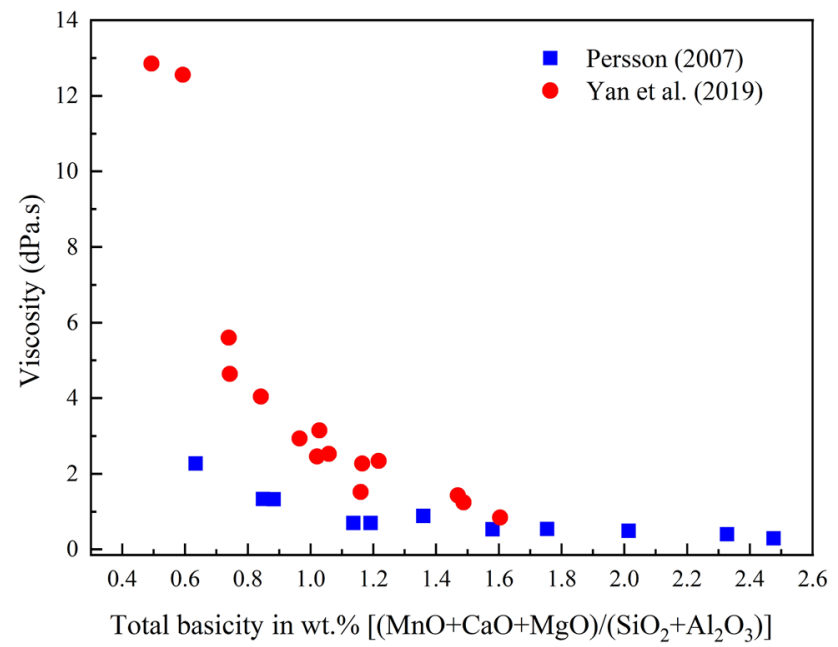

Fig. 21-Experimental viscosities (dPa.s) with respect to total basicity (wt pct) for the $\mathrm{MnO}-\mathrm{SiO}_{2}-\mathrm{CaO}-\mathrm{MgO}-\mathrm{Al}_{2} \mathrm{O}_{3}$ system. Comparing results from Persson 70 at $1550{ }^{\circ} \mathrm{C}$ to $1555{ }^{\circ} \mathrm{C}$ and $\mathrm{Yan}$ et al. ${ }^{71}$ at $1550{ }^{\circ} \mathrm{C}$.

Figure 20 shows the viscosity measurements $(\mathrm{dPa}$ s) with respect to the temperature $\left({ }^{\circ} \mathrm{C}\right)$ for Slag A, B, and C. As expected, viscosities were decreased by increasing $\mathrm{MnO}$ from 30 to $50 \mathrm{wt}$ pet for all slag groups.
Comparing the viscosities for slags containing the same amount of $\mathrm{MnO}$ suggested that slags with the highest amount of $\mathrm{CaO}$ possess the lowest viscosities, namely Slag D, while the highest viscosity values were reported for slags containing the highest amounts of $\mathrm{SiO}_{2}$ and $\mathrm{Al}_{2} \mathrm{O}_{3}$, namely Slag $\mathrm{C}$. It was also noted that the viscosity increases significantly below liquidus temperature because of the presence of solid particles. It is worth noting that $\mathrm{MnO}$ content further enhances the viscosity, due to higher amount of solid particles, compared to counterparts with a low amount of $\mathrm{MnO}$, with smaller amount of solid particles.

Yan et $a l^{[71]}$ studied viscosity both experimentally and theoretically for the $\mathrm{MnO}$ (0 to $55 \mathrm{wt}$ pct) $-\mathrm{SiO}_{2^{-}}$ $\mathrm{CaO}-\mathrm{MgO}$ (5 wt pct) $-\mathrm{Al}_{2} \mathrm{O}_{3}$ (20 wt pet) system in the temperature range from $1300{ }^{\circ} \mathrm{C}$ to $1600{ }^{\circ} \mathrm{C}$. The $\mathrm{SiO}_{2}$ and $\mathrm{CaO}$ contents were varied from 11 to 48 and 7 to 45 wt pct, respectively. The studied compositions were similar to the slags in FeMn- and SiMn-production. The results showed that the viscosity goes down by increasing $\mathrm{MnO}$, specifically in melts with higher ratio of $\mathrm{CaO}$ to $\mathrm{SiO}_{2}{ }^{[71]}$ The addition of 5 wt pet $\mathrm{MnO}$ increased the viscosities considerably for melts with the ratio of $\mathrm{CaO}$ to $\mathrm{SiO}_{2}$ equal to 1.0 and 1.5 , while the viscosity was only slightly reduced for the slag system with the ratio of $\mathrm{CaO}$ to $\mathrm{SiO}_{2}$ equal to 0.6. 
Table IV. Chemical Composition of Slags in FeMn and SiMn Production

Chemical Composition (Wt Pct)

\begin{tabular}{|c|c|c|c|c|c|c|}
\hline Slag & $\mathrm{MnO}$ & $\mathrm{CaO}$ & $\mathrm{MgO}$ & $\mathrm{SiO}_{2}$ & $\mathrm{Al}_{2} \mathrm{O}_{3}$ & Other \\
\hline $\begin{array}{l}\text { High MnO- } \\
\text { FeMn production }\end{array}$ & 28.0 to 30.0 & 28.0 to 30.0 & 6.0 to 6.5 & 28.0 to 30.0 & 5.0 to 5.5 & 1.0 to 1.3 \\
\hline $\begin{array}{l}\text { Low MnO- } \\
\text { SiMn production }\end{array}$ & 10.9 & 28.1 & 7.3 & 32.5 & 21.1 & 0.1 \\
\hline
\end{tabular}

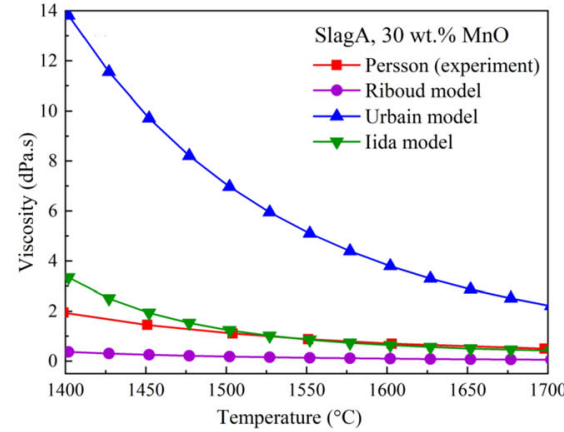

(a)

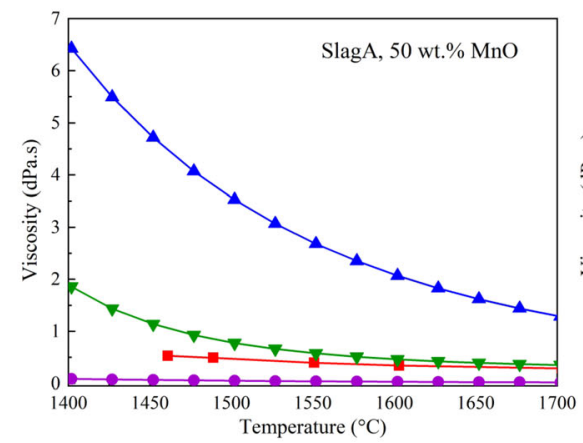

(d)

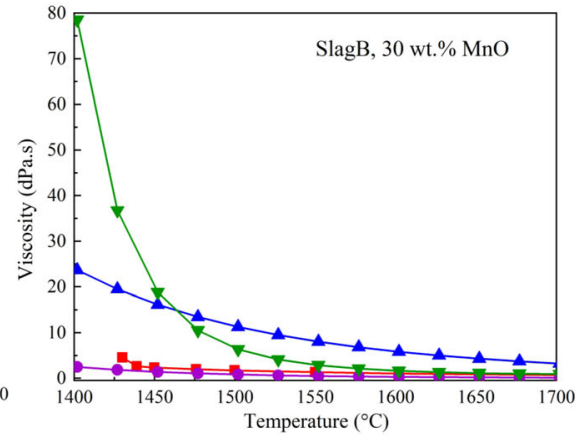

(b)

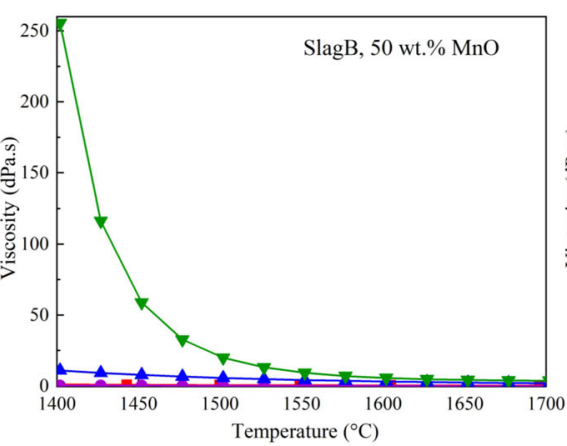

(e)

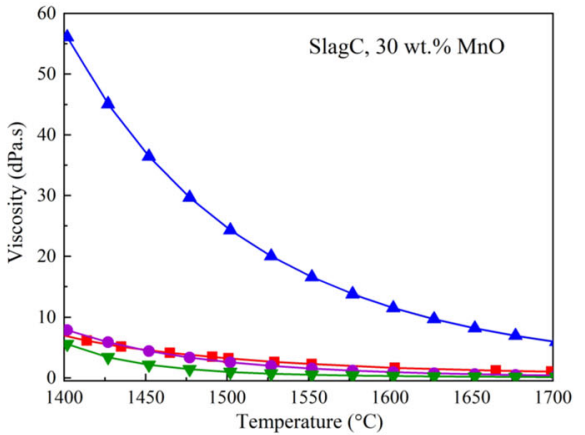

(c)

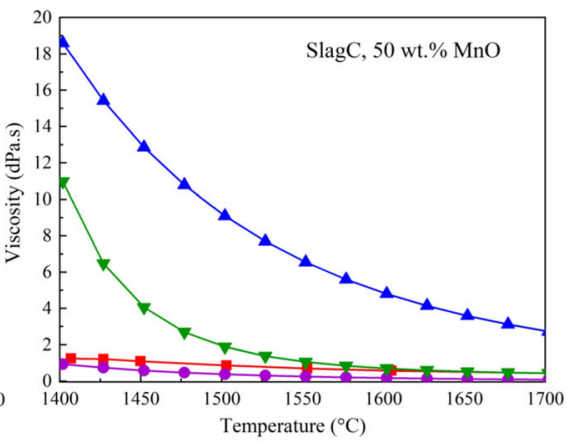

(f)

Fig. 22-Viscosity variations (dPa.s) vs. temperature $\left({ }^{\circ} \mathrm{C}\right.$ ). Comparison of viscosities reported by Persson ${ }^{[70]}$ with models from Riboud ${ }^{[84]}$, Urbain $^{[85]}$, and Iida ${ }^{[86]}$ for Slags A to C containing 30 and $50 \mathrm{wt}$ pct MnO. (a) to $(f)$ represents slag composition from Table III. (a) Slag A30, (b) Slag B30 (c) Slag C30, (d) Slag A50, (e) SlagB50 and (f) Slag C50.

Figure 21 exhibits the viscosity variations with respect to the total basicity (wt pct) defined as $[(\mathrm{MnO}+$ $\left.\mathrm{CaO}+\mathrm{MgO}) /\left(\mathrm{SiO}_{2}+\mathrm{Al}_{2} \mathrm{O}_{3}\right)\right]$ for data reported by Persson $(2007)^{[70]}$ at $1550{ }^{\circ} \mathrm{C}$ to $1555^{\circ} \mathrm{C}$ and Yan et al. ${ }^{[71]}$ at $1550{ }^{\circ} \mathrm{C}$. As expected, the viscosity reduces by increasing the basicity in both studies, while the measured viscosity magnitudes by Yan et al. is larger than those viscosity values by Persson, specifically in lower basicities.

Although viscosity measurements have been performed on various slag systems, it is extremely challenging to produce experimental data for the entire range of compositions and temperatures. Furthermore, the high-temperature viscosity measurement is practically both time-consuming and high-cost. Accordingly, several models have been developed to predict slag viscosity for systems containing MnO. ${ }^{[71,74,76,78-83]}$ The viscosity has been estimated for various binary, ternary, quaternary, and multicomponent systems. Comparing predicted viscosity values with experimental data has demonstrated that the models can provide reliable estimations of viscosity behavior with respect to both temperature and slag compositions.

In Figure 22, experimental viscosity results from Persson 70 are compared to the models proposed by Riboud 84, Urbain 85, and Iida 86 which depend only on slag compositions and temperature. It can be found that while the Urbain model overestimates the experimental data for all compositions presented, two other models predict better values especially the Iida model for the temperatures above $1550{ }^{\circ} \mathrm{C}$. For slags in group $\mathrm{B}$ containing the lowest content of $\mathrm{SiO}_{2}$ and highest content of $\mathrm{Al}_{2} \mathrm{O}_{3}$, the Iida model shows large variations with respect to temperatures lower than $1500{ }^{\circ} \mathrm{C}$. 


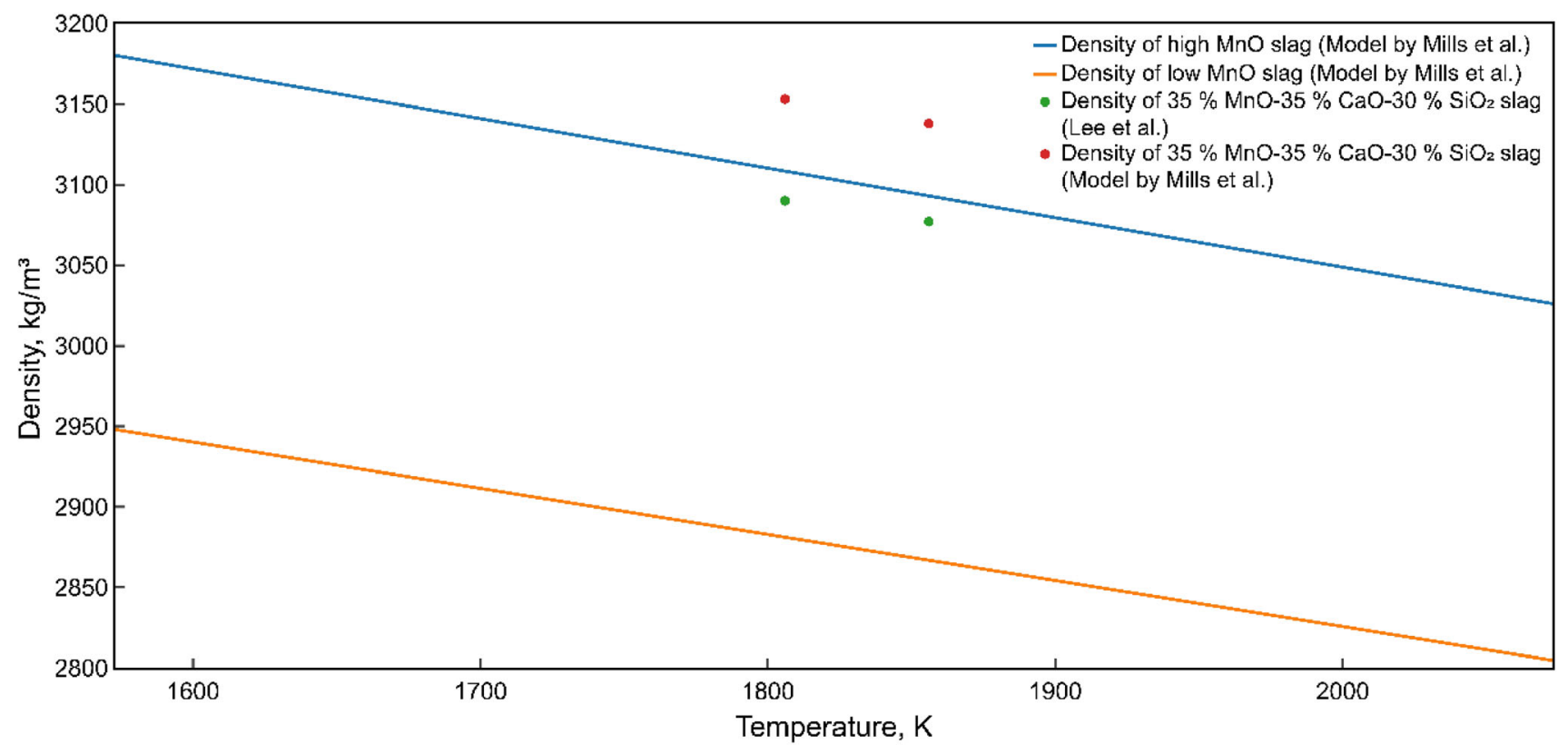

Fig. 23-Density of multicomponent MnO-containing slags. Composition of low and high MnO slags is shown in Table IV.

\section{Density}

There is a lack of density data on slags in Mn-ferroalloy production, but some insight may be gained by considering slags in steel production. Particularly, so-called mould slags in steel production consist of similar components as slags in Mn-ferroalloy production, $\mathrm{MnO}, \mathrm{CaO}, \mathrm{MgO}, \mathrm{SiO}_{2}, \mathrm{Al}_{2} \mathrm{O}_{3}$, while the main difference is the content of these components in both types of slags. ${ }^{[87]}$

In general, slag density can be determined by (a) numerical calculations based on previously established models ${ }^{[88]}$ and (b) experimental methods, such as the sessile drop technique ${ }^{[89]}$ the Archimedes principle ${ }^{[90]}$ or electrostatic levitation method. ${ }^{[91]}$

One of the most well-known numerical methods for calculating density of a multicomponent slag in liquid state is based on calculation of partial molar volumes, ${ }^{[88]}$ which are expressed as:

$$
\begin{array}{r}
V_{1773}=\sum_{i=1}^{N} X_{i} V_{i} \\
V_{T}=V_{1773}+0.01(T-1773 \mathrm{~K})
\end{array}
$$

where $V_{1773}$ is slag partial molar volume of at 1773 $\mathrm{K},{ }^{[88,92]} X_{i}$ is molar fraction of a component, $V_{i}$ is partial molar volume of a component at $1773 \mathrm{~K}, V_{T}$ is slag partial molar volume at a certain temperature in liquid state and $T$ is the certain temperature in liquid state.

Subsequently, density is defined as:

$$
\rho_{T}=\frac{M}{V_{T}}
$$

where $\rho_{T}$ is density liquid state, $M$ is mean molecular weight of all components in slag.

Figure 23 illustrates a comparison of the experimentally measured densities by Lee at al.93 and the calculated densities by the model from Mills et al. ${ }^{2}$ for $\mathrm{MnO}-\mathrm{CaO}-\mathrm{SiO}_{2}-\mathrm{MgO}-\mathrm{Al}_{2} \mathrm{O}_{3}$ and $\mathrm{MnO}-\mathrm{CaO}-\mathrm{SiO}_{2}$ slags. The density of $\mathrm{MnO}-\mathrm{CaO}-\mathrm{SiO}_{2}$ slag estimated using the model shows fairly close values to those determined by Lee et al., and in addition, the calculated densities show the expected increase when $\mathrm{MnO}$ content is increased, which may indicate that the model of Mills et al. can be applied for slags in ferroalloy production with high reproducibility.

\section{Surface and Interfacial Tension}

Surface and interfacial tensions govern important phenomena such as wetting, foaming, refractory infiltration and slag-metal separation. ${ }^{96-98]}$ Interfacial behaviour depends upon the content of chemical elements and components interacting at the slag-metal interface, and thus interfacial tension changes as a function of slag composition. As with other properties of slags in ferroalloy production, there are few published data on surface tension of multicomponent slags and interfacial tension between slag and ferroalloys. However, studies on slags in steel production have shown that surface tension of most multicomponent slags lies in the range from 0.30 to $0.70 \mathrm{~N} / \mathrm{m} \cdot{ }^{[99-101]}$ Bublik et al. ${ }^{102}$ have found that surface tension of slags corresponding to $\mathrm{FeMn}$ and $\mathrm{SiMn}$ production are 0.65 and $0.50 \mathrm{~N} / \mathrm{m}$, respectively. 


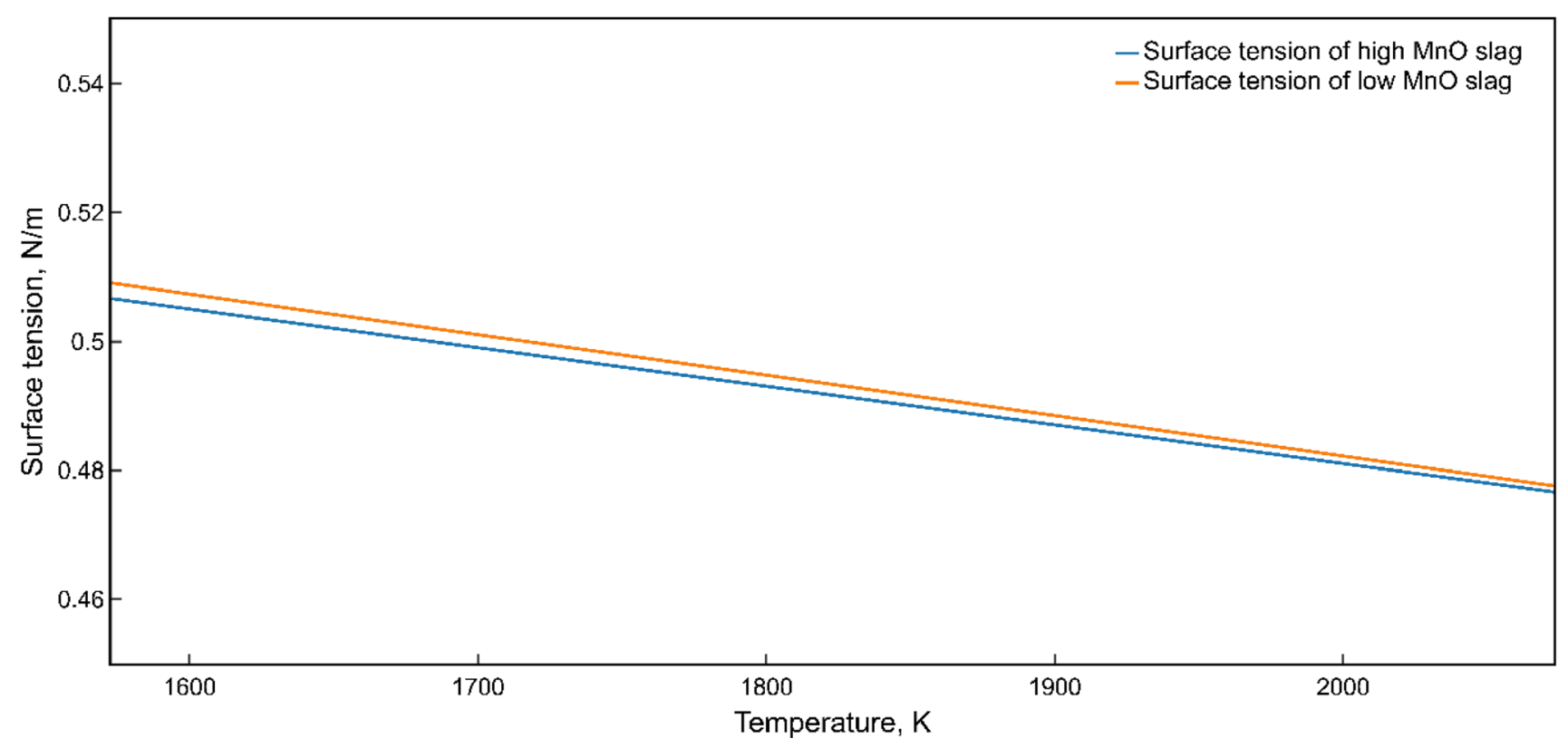

Fig. 24 - Surface tension of high and low MnO slags. Composition of low- and high-MnO slags is shown in Table IV.

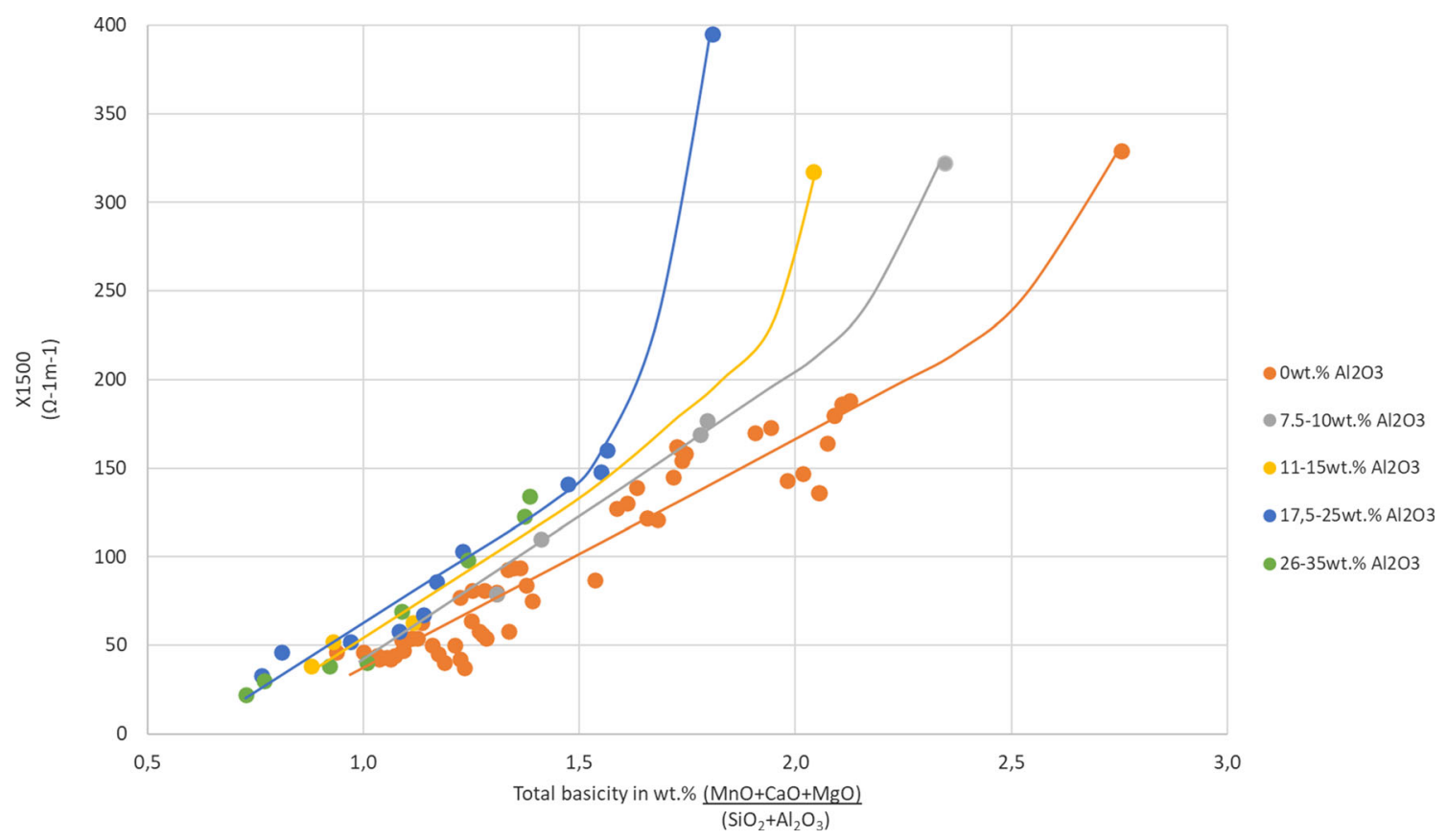

Fig. 25-Electrical conductivity vs. total basicity in wt pet for slags with various $\mathrm{Al}_{2} \mathrm{O}_{3}$ contents. The 4 non-linear points giving the electrical resistivity $250 \mathrm{~S} / \mathrm{m}$, are the slags with an $\mathrm{MnO}$ content above $65 \mathrm{wt}$ pet [data used ${ }^{[108]}$ ].

Mills et $a .^{88}$ have reported that surface tension of multicomponent slags can be calculated assuming that surface tension is temperature-dependent and that all slag components modify surface tension depending on the mole fraction and their content in the bulk or at the surface. As such, $\mathrm{Na}_{2} \mathrm{O}, \mathrm{K}_{2} \mathrm{O}, \mathrm{CaF}_{2}$ and $\mathrm{B}_{2} \mathrm{O}_{3}$ are treated as surfactants, while others as bulk components. Surface tension is then calculated using a system of equations:

$$
\begin{array}{r}
\gamma_{T}=\gamma_{1773}+\frac{\mathrm{d} \gamma}{\mathrm{d} T}(T-1773 \mathrm{~K}) \\
\gamma_{1773}=\left(\sum_{i=1}^{N} X_{i} \gamma_{i}\right)_{\text {bulk }}+\left(\sum_{i=1}^{N} X_{i} \gamma_{i}\right)_{\text {surf }} \\
\frac{\mathrm{d} \gamma}{\mathrm{d} T}=\sum_{i=1}^{N} X_{i} \frac{\mathrm{d} \gamma_{i}}{\mathrm{~d} T}
\end{array}
$$




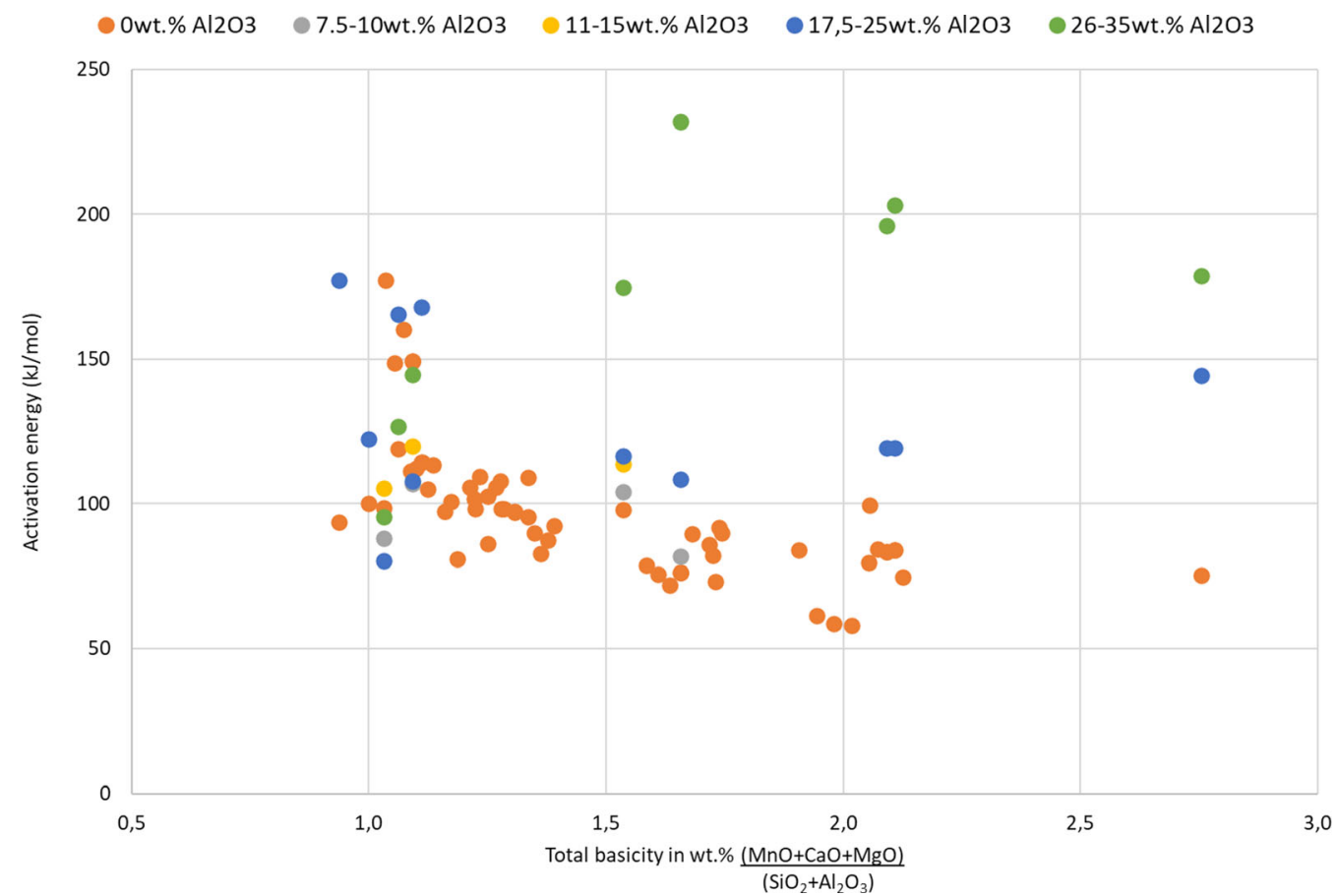

Fig. 26-Activation energy of the conductivity of slags vs. total basicity in wt pet for slags with various $\mathrm{Al}_{2} \mathrm{O}_{3}$ content (data from Ref. 108).
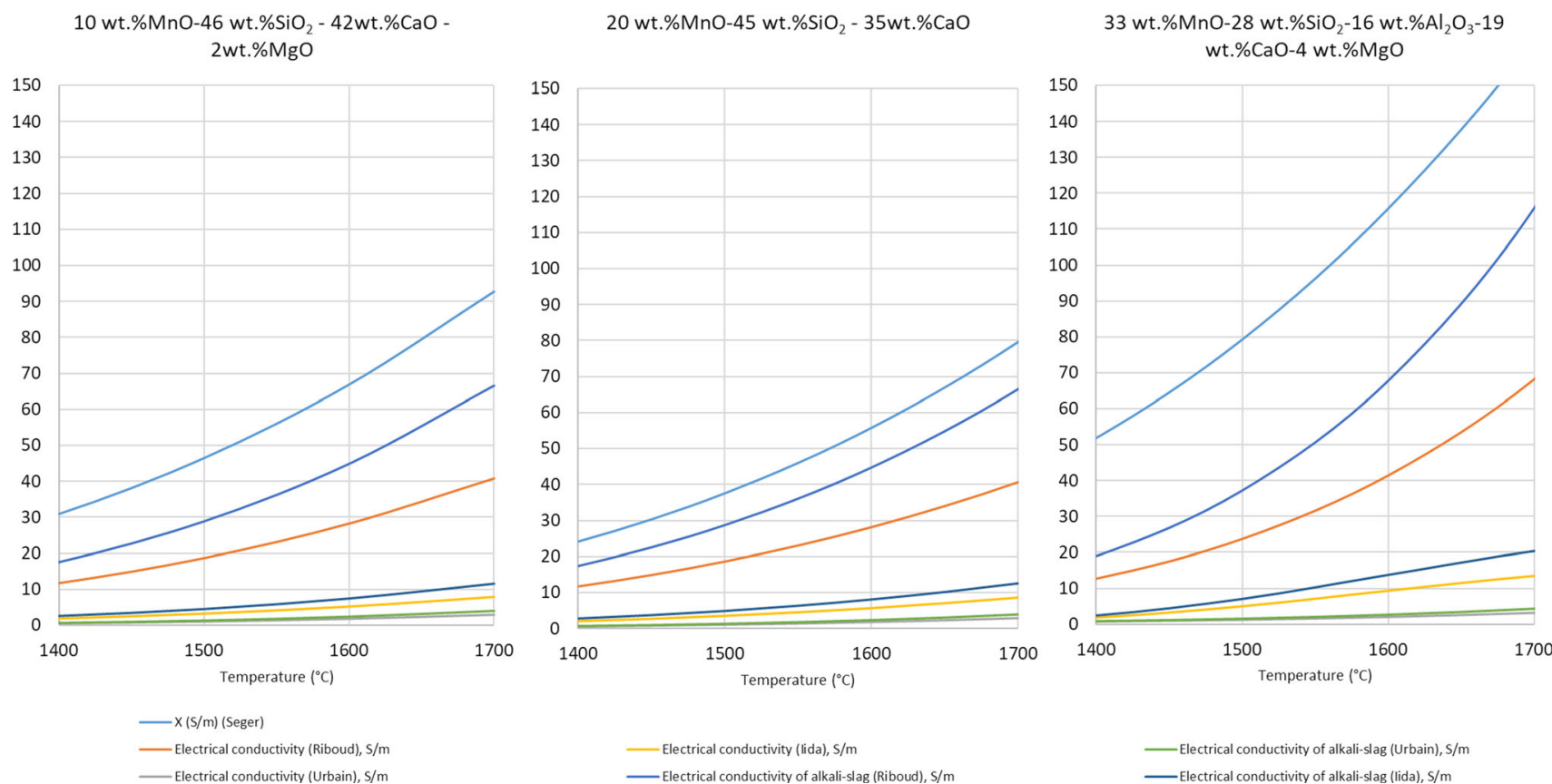

-Electrical conductivity (lida), $\mathrm{s} / \mathrm{m}$
Electrical conductivity of alkali-slag (Riboud), $\mathrm{s} / \mathrm{m}$

Electrical conductivity of alkali-slag (Urbain), $\mathrm{s} / \mathrm{m}$

Fig. 27-Comparison of electrical conductivity ( $\mathrm{S} / \mathrm{m}$ ) measured by Segers et al. with models from Riboud, Urbain and Iida of close to two SiMn slags and one FeMn slag. Though there are some differences, it is the alkali Riboud model that has the smallest deviation from the experimental data, followed by the Riboud model. 
where $\gamma_{\mathrm{T}}$ and $\gamma_{1773}$ are surface tension at a certain temperature and $1773 \mathrm{~K}$, respectively.

Values of surface tension calculated using this model for slags as shown in Table IV is illustrated in Figure 24.

Sulfur and other surface-active elements have a significant influence on interfacial tension in liquid systems because they can affect the interfacial interaction at the slag-metal interface. ${ }^{[103-105]}$ As a result, low interfacial tension leads to the formation of a slag-metal emulsion, metal droplet entrainment during tapping, and therefore poor slag-metal separation. Cramb et al. ${ }^{106}$ have shown that interfacial tension between steel and slag sharply decreases with an increase of sulfur or oxygen activity. Bublik et al. ${ }^{102}$ have suggested that higher sulfur content in ferroalloy-slag systems results in a higher mass transfer rate at the slag-metal interface, which again decreases both interfacial tension and apparent contact angle between slag and ferroalloys.

\section{E. Electrical Conductivity}

The electrical conductivity of slags in the steelmaking area, that is $\mathrm{MgO}, \mathrm{CaO}, \mathrm{SiO}_{2}$ and $\mathrm{Al}_{2} \mathrm{O}_{3}$ has been investigated by several researchers and to mention one recent review on this system Wang et al. ${ }^{107}$ can be mentioned. In the five component system including $\mathrm{MnO}$, there is one main reference and that is Seger et al. ${ }^{108}$. Seger and his group experimentally determined the slag from a basicity $[=(\mathrm{CaO}+\mathrm{MgO})$ $\left.\left(\mathrm{SiO}_{2}+\mathrm{Al}_{2} \mathrm{O}_{3}\right)\right]$ from 0 to 0.93 and from 10 to 73 pct $\mathrm{MnO}$, that is within the area of $\mathrm{FeMn}$ and $\mathrm{SiMn}$ production. The electrical conductivity at $1500{ }^{\circ} \mathrm{C}$ are shown in Figure 25. The tapping slags for FeMn and SiMn will typically be above $150 \mathrm{~S} / \mathrm{m}$ and $40-120 \mathrm{~S} / \mathrm{m}$ respectively. Overall, the electrical conductivity increases with basicity, and as the conductivity is shown as a function of the total basicity, including all 5 components, the conductivity of slags with higher alumina contents will be slightly higher, as alumina is less acid compared to silica. Most of the slags have a linear relationship between the total basicity and the conductivity, and the only exemption is the 4 points with higher than 65 wt pet $\mathrm{MnO}$ and no $\mathrm{CaO}$ and $\mathrm{MgO}$, which shows conductivities higher than $300 \mathrm{~S} / \mathrm{m}$. It can however be mentioned that the $\mathrm{MnO} /(\mathrm{CaO}+\mathrm{MgO})$ ratio has no significant effect on the rest of the data.

The electrical conductivity is dependent on temperature and can be given by the Arrhenius equation where $X(\mathrm{~S} / \mathrm{m})$ is conductivity, $A$ is pre-exponential factor $(\mathrm{S} /$ $\mathrm{m}), E$ is activation energy in $\mathrm{kJ} / \mathrm{mol}, R$ is gas constant $(8.314 \mathrm{~J} / \mathrm{mol} / \mathrm{K})$ and $T$ is temperature $(\mathrm{K})$ :

$$
X=A \cdot \exp \left(\frac{-E}{R T}\right)
$$

The activation energy, representing the temperature dependence of the conductivity of the slag, varies between $50-350 \mathrm{~kJ} / \mathrm{mol}$ as can be seen in Figure 26 . There is an indication that the activation energy of the low alumina slags decreases with basicity, while it increases for the high alumina slags.
As both the viscosity and the electrical conductivity is dependent on the slag structure, a correlation between the electrical conductivity and the viscosity has been proposed ${ }^{[109]}$ Based on the viscosity models of Riboud 110, Urbain 85 and Iida 86 one can hence calculate the electrical conductivity from slag composition and temperature, and in Figure 27 the experimental data from Segers et al. has been compared to the models. It can be seen that the experimental data are much higher compared to the models, however the Riboud alkalimodel $^{[109,110]}$ gives the best fit.

\section{ACKNOWLEDGMENTS}

This publication has been partly funded by the SFI Metal Production, (Centre for Research-based Innovation, 237738) and Controlled Tapping (267621). The authors gratefully acknowledge the financial support from the Research Council of Norway and the partners of the SFI Metal Production and Controlled Tapping.

\section{CONFLICT OF INTEREST}

On behalf of all authors, the corresponding author states that there is no conflict of interest.

\section{FUNDING}

Open access funding provided by NTNU Norwegian University of Science and Technology (incl St. Olavs Hospital - Trondheim University Hospital).

\section{OPEN ACCESS}

This article is licensed under a Creative Commons Attribution 4.0 International License, which permits use, sharing, adaptation, distribution and reproduction in any medium or format, as long as you give appropriate credit to the original author(s) and the source, provide a link to the Creative Commons licence, and indicate if changes were made. The images or other third party material in this article are included in the article's Creative Commons licence, unless indicated otherwise in a credit line to the material. If material is not included in the article's Creative Commons licence and your intended use is not permitted by statutory regulation or exceeds the permitted use, you will need to obtain permission directly from the copyright holder. To view a copy of this licence, visit http://creat ivecommons.org/licenses/by/4.0/.

\section{REFERENCES}

1. S. Olsen, M. Tangstad, and T. Lindstad: Production of Manganese Ferroalloys, Tapir, Trondheim, 2007. 
2. D. Slizovskiy and M. Tangstad: Infacon, Helsinki, 2010.

3. D. Slizovskiy and M. Tangstad: Infacon, Almaty, Kazakhstan, 2013, pp. 185-94.

4. D. Slizovskiy: Doctoral Thesis, NTNU, Norway 2012.

5. M. Tangstad: Handbook of Ferroalloys, Elsevier, Amsterdam, 2013, pp. 221-66.

6. M. Tangstad, E. Ringdalen, E. Manilla, and D. Davila: in 7th International Symposium on High-Temperature Metallurgical Processing, J.-Y. Hwang, T. Jiang, P.C. Pistorius, G.R.F. Alvear F., O. Yücel, L. Cai, B. Zhao, D. Gregurek, and V. Seshadri, eds., Springer, Cham, 2016, pp. 181-88.

7. M. Tangstad, P. Calvert, H. Brun, and A.G. Lindseth: Infacon, Cape Town, 2004, pp. 213-22.

8. H. Lagendijk, B. Xakalashe, T. Ligege, P. Ntikang, and K. Bisaka: Infacon, Helsinki, 2010, pp. 497-508.

9. M. Eissa, H. El-Faramawy, A. Ahmed, S. Nabil, and H. Halfa: $J$. Miner. Mater. Charact. Eng., 2012, vol. 11, pp. 1-20.

10. T. Coetsee, C. Reinke, J. Nell, and P.C. Pistorius: Metall. Mater. Trans. B, 2015, vol. 46, pp. 2534-52.

11. M. Tangstad, E. Ringdalen, E. Manilla, and D. Davila: JOM, 2017, vol. 69, pp. 358-64.

12. N.A. Barcza, A. Koursaris, J.B. See, and W.A. Gericke: vol. 37, Iron \& Steel Society of AIME, Detroit, 1979, pp. 19-33.

13. M. Tangstad: PhD-thesis, NTH, Norway, 1996.

14. M. Tangstad, B.Heiland, S.E.Olsen,R.Tronstad: INFACON, Canada, 2001, p. 6.

15. B. Monsen, M. Tangstad, and H. Midtgaard: Infacon,Cape Town, South Africa, 2004, pp. 392-404.

16. S.E. Olsen and M. Tangstad: Infacon, vol. 10, Cape Town, South Africa, 2004, pp. 231-38.

17. B. Monsen, M. Tangstad, I. Solheim, M. Syvertsen, R. Ishak, and H. Midtgaard: Infacon, vol. 11, The Indian Ferro Alloy Producers' Association, New Delhi, 2007, pp. 297-10.

18. E. Ringdalen and I. Solheim: Infacon, Southern African Institute of Mining and Metallurgy, Cape Town, 2018.

19. E. Ringdalen and M. Tangstad: Infacon, Almaty, Kazakhstan, 2013, pp. 195-206.

20. K. Tang and S.E. Olsen: Infacon, The Southern African Institute of Mining and Metallurgy, Cape Town, 2004.

21. D. Leroy: Master thesis, NTNU, Norway, 2007.

22. R. Rait and S.E. Olsen: Infacon, Helsinki, 2000.

23. E. Haccuria, P.C. Hayes, and E. Jak: Int. J. Mater. Res., 2015, vol. 106 , pp. 225-36.

24. B. Zhao, E. Jak, and P.C. Hayes: ISIJ Int., 2006, vol. 46, pp. $1594-1602$.

25. E. Ringdalen, M. Tangstad, and S. Gaal: in Proceedings of the VIII International Conference on Molten Slags, Fluxes and Salts: 18 - 21 January 2009, Santiago, Chile, M. Sanchez and Universidad de Concepción, eds., 1. ed., GECAMIN, Santiago, 2009.

26. T. Brynjulfsen and M. Tangstad: Infacon, Almaty, Kazakhstan, 2013, pp. 137-48.

27. M. Visser, H. Smith, E. Ringdalen, and M. Tangstad: Infacon in MANGANESE FUNDAMENTALS, Almaty, Kazakhstan, 2013, pp. 553-66.

28. E. Ringdalen, M. Tangstad, and T. Brynjulfsen: Infacon in FUNDAMENTALS, THEORY, Kiev, Ukraine, 2015.

29. B. Sorensen, S. Gaal, E. Ringdalen, M. Tangstad, R. Kononov, and O. Ostrovski: in INFACON XII, Helsinki, 2010, pp. 439-48.

30. T. Brynjulfsen and M. Tangstad: in Characterization of Minerals, Metals, and Materials, J.-Y. Hwang, S.N. Monteiro, C.-G. Bai, J. Carpenter, M. Cai, D. Firrao, and B.-G. Kim, eds., Wiley, Hoboken, NJ, 2012, pp. 147-54.

31. D. Slizovskiy, M. Tangstad, and S. Wasbø: unpublished research 2021

32. P.P. Kim, J. Holtan, and M. Tangstad: in Advances in Molten Slags, Fluxes, and Salts: Proceedings of the 10th International Conference on Molten Slags, Fluxes and Salts 2016, R.G. Reddy, P. Chaubal, P.C. Pistorius, and U. Pal, eds., Springer, Cham, 2016, pp. 1285-92.

33. P.P. Kim and M. Tangstad: Metall. Mater. Trans. B, 2018, vol. 49B, pp. 1185-96.

34. J. Holtan: Master thesis, NTNU, Norway, 2016.

35. T.A. Larssen: Master thesis, NTNU, Norway, 2017.

36. S. Maroufi, G. Ciezki, S. Jahanshahi, S. Sun, and O. Ostrovski: Metall. Mater. Trans. B, 2015, vol. 46B, pp. 101-108.
37. D. Swinbourne, W.J. Rankin, and R.H. Eric: Metall. Mater. Trans. B, 1995, vol. 26B, pp. 59-65.

38. H. Cengizler and R.H. Eric: vol. 1, Southern African Institute of Mining and Metallurgy, Cape Town, South Africa, 1992, pp. $167-74$.

39. A.L. Oklei, T.A. Chubnidize, and G.G. Arevadze: J. Appl. Chem. USSR, 1991, pp. 1565-68.

40. V. Olsø, M. Tangstad, and S.E. Olsen: Infacon, Beijing, China, 1998, pp. 279-83.

41. Y.E. Lee: Encyclopedia of Materials: Science and Technology, Elsevier, Amsterdam, 2001, pp. 3039-44.

42. O. Ostrovski, S.E. Olsen, M. Tangstad, and M. Yastreboff: Can. Metall. Q., 2002, vol. 41, pp. 309-18.

43. J.M.A. Geldenhuis, E.B. Pretorius, and R.J. Dippenaar: The South African Institute of Mining and Metallurgy, Cape Town, 1992.

44. T. Brynjulfsen: Doctoral Thesis, NTNU, Norway 2013.

45. D. Mwana Bute Ngoy, M. Kalenga wa Kalenga, and M. Tangstad: Metallurgist, 2018, vol. 62, pp. 658-66.

46. X. Li, K. Tang, and M. Tangstad: Minerals, 2020, vol. 10, p. 97.

47. T.-A. Skjervheim: PhD, NTH, Norway, 1994.

48. B. Nadir: Master thesis, NTNU, Norway, 2015.

49. X. Li and M. Tangstad: Metall. Mater. Trans. B, 2019, vol. 50B, pp. $136-49$

50. V. Canaguier and M. Tangstad: Metall. Mater. Trans. B, 2020, vol. 51B, pp. 953-62.

51. P. Kim, T. Larssen, M. Tangstad, and R. Kawamoto: in Applications of Process Engineering Principles in Materials Processing, Energy and Environmental Technologies, S. Wang, M.L. Free, S. Alam, M. Zhang, and P.R. Taylor, eds., Springer, Cham, 2017, pp. $475-83$

52. G. Tranell, S. Gaal, D. Lu, M. Tangstad, and J. Safarian: Infacon, The Indian Ferro Alloy Producers' Association, New Delhi, 2007, pp. 231-40.

53. B.D. Hosum: Master thesis, NTNU, Norway, 2020.

54. V. Canaguier and M. Tangstad: Metall. Mater. Trans. B, 2020, vol. 51 (3), pp. 952-63.

55. P.P. Kim: Doctoral Thesis, NTNU, Norway, 2018.

56. B.O. Mysen, D. Virgo, and F.A. Seifert: Rev. Geophys., 1982, vol. 20 , p. 353

57. K.C. Mills: ISIJ Int., 1993, vol. 33, pp. 148-55.

58. J.H. Park: ISIJ Int., 2012, vol. 52, pp. 1627-36.

59. J.H. Park: J. Non-Cryst. Solids, 2012, vol. 358, pp. 3096-102.

60. K.C. Mills, L. Yuan, Z. Li, G. Zhang, and K. Chou: High Temp. Mater. Process., 2012, vol. 31, pp. 301-21.

61. B. Mysen and P. Richet: Silicate Glasses and Melts, Elsevier, Amsterdam, 2019, pp. 223-62.

62. I. Sohn and D.J. Min: Steel Res. Int., 2012, vol. 83, pp. 611-630.

63. J.H. Park, K.Y. Ko, and T.S. Kim: Metall. Mater. Trans. B, 2015, vol. 46B, pp. 741-48.

64. J.B. Kim and I. Sohn: ISIJ Int., 2014, vol. 54, pp. 2050-58.

65. T.S. Kim and J.H. Park: J. Am. Ceram. Soc., 2019, vol. 102, pp. 4943-55.

66. T.S. Kim, S.J. Jeong, and J.H. Park: Met. Mater. Int., 2020, vol. 26, pp. 1872-80.

67. C. Han: PhD Thesis, The University of Queensland, Australia, 2017.

68. I. Tanabe, K. Oku, and T. Honda: J. Electrochem. Soc. Jpn., 1960, vol. 28, pp. E262-66.

69. L.C. Woolacott, D.D. Howat, and P.R. Jochens: South African Institute of Mining and Metallurgy, Johannesburg, South Africa, 1974 , pp. 227-32.

70. M. Persson: PhD Thesis, Royal Institute of Technology, Sweden, 2007.

71. B. Yan, Y. Liu, Q. Shu, T. Deng, and B. Glaser: Metall. Mater. Trans. B, 2019, vol. 50B, pp. 376-84.

72. L. Segers, A. Fontana, and R. Winand: Electrochim. Acta, 1979, vol. 24, pp. 213-18.

73. G. Urbain, Y. Bottinga, and P. Richet: Geochim. Cosmochim. Acta, 1982, vol. 46, pp. 1061-72.

74. S. Sridhar, D. Sichen, S. Seetharaman, and K.C. Mills: Steel Res., 2001, vol. 72, pp. 3-10.

75. F-.Z. Ji: Metall. Mater. Trans. B, 2001, vol. 32B, p. 181

76. F-.Z. Ji, D. Sichen, and S. Seetharaman: Int. J. Thermophys., 1999, vol. 20, pp. 309-23. 
77. M. Kato and S. Minowa: Trans. Iron Steel Inst. Jpn., 1969, vol. 9, pp. 31-38.

78. L. Zhang and S. Jahanshahi: Metall. Mater. Trans. B, 1998 , vol. 29B, pp. 177-86.

79. S. Vargas, F.J. Frandsen, and K. Dam-Johansen: Prog. Energy Combust. Sci., 2001, vol. 27, pp. 237-29.

80. K. Tang and M. Tangstad: vol. 11, Infacon, The Indian Ferro Alloy Producers' Association, New Delhi, 2007, pp. 345-57.

81. G-.H. Zhang, K-.C. Chou, Q-.G. Xue, and K.C. Mills: Metall. Mater. Trans. B, 2012, vol. 43B, pp. 64-72.

82. M.A. Duchesne, A.M. Bronsch, R.W. Hughes, and P.J. Masset: Adv. Coal Sci. Technol. ICCST 2011, 2013, vol. 114, pp. 38-43.

83. W-.Y. Kim, A. Pelton, C. Bale, E. Bélisle, and S. Decterov: $J$. Miner. Metall. Sect. B, 2013, vol. 49, pp. 323-37.

84. P.V. Riboud, Y. Roux, L.D. Lucas, and H. Gaye: Fachber Huttenprax Met., 1981, vol. 19, pp. 859-69.

85. G. Urbain: Steel Res., 1987, vol. 58, pp. 111-16.

86. T. Iida, H. Sakai, Y. Kita, and K. Shigeno: ISIJ Int., 2000, vol. 40 , pp. S110-14.

87. K.C. Mills and C-.Å. Däcker: The Casting Powders Book, Springer, Cham, 2017.

88. K.C. Mills, S. Karagadde, P.D. Lee, L. Yuan, and F. Shahbazian: ISIJ Int., 2016, vol. 56, pp. 264-73.

89. M.A. Duchesne and R.W. Hughes: Fuel, 2017, vol. 188, pp. 173 81.

90. L. Muhmood and S. Seetharaman: Metall. Mater. Trans. B, 2010, vol. 41B, pp. 833-40.

91. T. Matsushita, T. Ishikawa, P-.F. Paradis, K. Mukai, and S. Seetharaman: ISIJ Int., 2006, vol. 46, pp. 606-10.

92. K.C. Mills and B.J. Keene: Int. Mater. Rev., 1987, vol. 32, pp. 1120.

93. J. Lee, L.T. Hoai, J. Choe, and J.H. Park: ISIJ Int., 2012, vol. 52, pp. $2145-48$.

94. D. Groot, D. Kazadi, H. Pollman, J. Villiers, T. Redtmann, and J.D. Steenkamp: Infacon13, Almaty, Kazakstan, 2013.
95. E. Ringdalen, S. Gaal, M. Tangstad, and O. Ostrovski: Metall. Mater. Trans. B, 2010, vol. 41B, pp. 1220-29.

96. Y. Wanibe, H. Tsuchida, T. Fujisawa, and H. Sakao: Trans. Iron Steel Inst. Jpn., 1983, vol. 23, pp. 322-30.

97. J. Wikström: PhD thesis, Royal Institute of Technology, Sweden, 2007.

98. R.A.M. de Almeida, D. Vieira, W.V. Bielefeldt, A.C.F. Vilela, R.A.M. de Almeida, D. Vieira, W.V. Bielefeldt, and A.C.F. Vilela: Mater. Res., 2017, vol. 20, pp. 474-80.

99. J. Xin, N. Wang, M. Chen, and L. Gan: ISIJ Int., 2019, vol. 59, pp. 759-67.

100. M. Hanao, T. Tanaka, M. Kawamoto, and K. Takatani: ISIJ Int., 2007, vol. 47, pp. 935-39.

101. M. Wegener, L. Muhmood, S. Sun, and A.V. Deev: Metall. Mater. Trans. B, 2015, vol. 46B, pp. 316-27.

102. S. Bublik, S. Bao, M. Tangstad, and K.E. Einarsrud: Metall. Mater. Trans. B, 2021, vol. 52, pp. 2847-58

103. L. Muhmood, N.N. Viswanathan, and S. Seetharaman: Metall. Mater. Trans. B, 2011, vol. 42B, pp. 460-70.

104. M. Suzuki, M. Nakamoto, T. Tanaka, Y. Tsukaguchi, K. Mishima, and M. Hanao: ISIJ Int., 2020, vol. 60, pp. 2332-38.

105. T. Tanaka, H. Goto, M. Nakamoto, M. Suzuki, M. Hanao, M. Zeze, H. Yamamura, and T. Yoshikawa: ISIJ Int., 2016, vol. 56, pp. $944-52$.

106. A.W. Cramb and I. Jimbo: Steel Res., 1989, vol. 60, pp. 157-65.

107. Y. Wang, L. Wang, and K-.C. Chou: High Temp. Mater. Process., 2016, vol. 35 , pp. 253-59.

108. L. Segers, A. Fontana, and R. Winand: Can. Metall. Q., 1983, vol. 22, pp. 429-35.

109. K. Mills: Southern African Pyro Metallurgy, The Southern African Institute of Mining and Metallurgy, Johannesburg, 2011.

110. D. Kalisz: Arch. Mater. Sci. Eng., 2012, vol. 58, pp. 164-70.

Publisher's Note Springer Nature remains neutral with regard to jurisdictional claims in published maps and institutional affiliations. 